\title{
Microclimate Characteristics and Evapotranspiration Estimates of Cucumber Plants in a Newly Developed Sunken Solar Greenhouse
}

\author{
Haijun Liu ${ }^{1, *(\mathbb{D})}$, Congyan Yin ${ }^{2}$, Xiaodong $\mathrm{Hu}^{3}$, Josef Tanny ${ }^{4,5}$ and Xiaopei Tang ${ }^{1}$ \\ 1 Beijing Key Laboratory of Urban Hydrological Cycle and Sponge City Technology, College of Water Sciences, \\ Beijing Normal University, Beijing 100875, China; tangxiaopei@mail.bnu.edu.cn \\ 2 College of Plant Science and Technology, Huazhong Agricultural University, Wuhan 430070, China; \\ 2005160006@cugb.edu.cn \\ 3 School of Water Resources and Environment, China University of Geosciences (Beijing), Beijing 100083, \\ China; huxix@126.com \\ 4 Institute of Soil, Water and Environmental Sciences, Agricultural Research Organization, The Volcani Centre, \\ P.O.B 15159 Rishon, LeZion 7505101, Israel; tanai@volcani.agri.gov.il \\ $5 \quad$ HIT-Holon Institute of Technology, POB 305, Holon 5810201, Israel \\ * Correspondence: shanxilhj@bnu.edu.cn; Tel.: +86-136-81334108
}

Received: 30 June 2020; Accepted: 11 August 2020; Published: 13 August 2020 updates

\begin{abstract}
In north China, vegetables are always cultivated in conventional solar greenhouses (SG), however, these structures cannot be used during most of the winter due to extremely low temperatures. In this study, a new type of a solar greenhouse named sunken solar greenhouse (SSG), where the inside soil surface is lowered 1-2 $\mathrm{m}$ below outside and the back wall is $5-8 \mathrm{~m}$ width at the bottom and 1.5-2 $\mathrm{m}$ on top, was investigated. Inside climatic variables were recorded and compared with those outside during seven cucumber cultivation seasons. Crop evapotranspiration $\left(\mathrm{ET}_{\mathrm{c}}\right)$ was estimated using the Penman-Monteith method. Results show that inside solar radiation was reduced by approximately $40 \%$, however days with a daily maximum inside temperature higher than $20^{\circ} \mathrm{C}$ accounted for $80-90 \%$ of the days during the winter, which greatly enhanced cucumber fruit production compared to common SGs. The reference crop evapotranspiration ( $\mathrm{ET}_{\mathrm{o}}$ ) inside the SSG was reduced by $27 \%$ compared to outside. The estimated $\mathrm{ET}_{\mathrm{c}}$ was generally lower than $4 \mathrm{~mm}$ day $^{-1}$, which resulted in a basal crop coefficient of 0.83 . In conclusion, the SSG is environmental-friendly, preferable for winter vegetable cultivation in north China, and can be useful for other regions of the world with cold winter conditions.
\end{abstract}

Keywords: sunken solar greenhouse; microclimate; decoupling coefficient; crop evapotranspiration; north China

\section{Introduction}

A greenhouse is an enclosed structure, that can provide suitable environmental conditions for the intensive production of various crops, especially high price crops or those cultivated during offseason. Crop yields in greenhouses are 2-3 times higher than those in the open field [1]. Therefore, greenhouses have been used worldwide [1,2]. Solar greenhouses (SG), are constructed with a north-facing back wall and a south-facing transparent cover. The back wall stores energy from solar radiation during the day and releases heat into the greenhouse at night. Such greenhouses are widely used because of the low running costs, mainly due to energy-saving [3,4]. Presently, in China, the area of vegetables cultivated in solar greenhouses is approximately 3.3 million ha [5]. However, in winter, crops cannot grow in the traditional solar greenhouse because of the low inside air and soil temperatures. Therefore, 
these greenhouses are mostly used in spring and autumn, while from December to February, when air temperatures are the lowest in a year, they are non-operational [6].

The sunken solar greenhouse (SSG) is a modified solar greenhouse, newly developed in north China. This new type of greenhouse is characterized by 1.0-2.0 m lower inside soil surface than outside compared with the standard SG, where inside and outside soil surfaces are almost at the same level. Besides, the thickness of the back wall of the SSG, which is $5-8 \mathrm{~m}$, is significantly larger than $0.25-0.6$ $\mathrm{m}$, typical of the SG [7-10]. These two factors make the SSG suitable for vegetable cultivation even during the coldest winter months of December to February when the standard SG is not operational.

The microclimate inside SGs, especially temperature and radiation, is a critical factor for crop cultivation [11]. In tropical regions with high solar radiation, the microclimate studies in SGs were aimed at reducing inside air temperature by top shading and ventilation [12]. However in regions with low winter temperatures, the microclimate in traditional and improved SGs was investigated with a focus on the plant performance, especially under extreme winter conditions [2,13-18]. For example, Ahamed et al. [19] modeled the microclimate inside a Chinese-style solar greenhouse in Canada during the coldest three winter months (December, January, and February). They reported that for extending the crop planting period, extra $13-20 \%$ supplemental heating energy was required for increasing daytime temperature from 19 to $23^{\circ} \mathrm{C}$, and $8-18 \%$ supplemental heat was needed for increasing nighttime temperature from 16 to $20^{\circ} \mathrm{C}$.

Several approaches were suggested to improve the heat storage and increase air temperature inside SGs, for example, solar heating with thermal energy storage [13], passive solar water-sleeve heating system [14], sliding cover and active heat storage [18], and heating $\left(\mathrm{CO}_{2}\right.$ supply) ventilation and optimal control system [20]. Gourdo et al. [14] reported that the use of the passive solar water-sleeve heating system during the winter period in Canarian solar greenhouses could increase the inside nighttime temperature by $3.1^{\circ} \mathrm{C}$ and reduce the relative humidity by $10 \%$, which increased tomato yield by $35 \%$. Hodge et al. [21] examined a winter solar greenhouse widely used in the northern USA. In this system, solar energy is stored in a below-ground rock bed and transferred into the rowing space at night, thus improving the inside climate environment to grow greens through the winter with little or no use of fossil fuels. However, these supplemental heating systems not only increase the cost of SG building and operational expenses, but are also used during a limited period (mostly in the cold winter), which reduces their efficiency on an annual timescale. Therefore, Shukla et al. [17] noted that greenhouses with thermal energy storage systems should be economically evaluated to determine if the additional energy conservation outweighs the extra capital cost of additional infrastructures.

Recently, a new type of SG, the sunken solar greenhouse (SSG), is increasingly used in north China. Growers using SSGs have a general understanding of specific production practices and crop cultivars (mostly being cucumber, tomato, and pepper) that thrive in this system. However, their knowledge is experience-based rather than research-based. Because of the deep soil surface and the much thicker back wall in the SSG, the microclimate inside may be significantly altered compared to the SG. Till now, there are no research reports about the microclimate and evapotranspiration in sunken solar greenhouses. Using active heating systems (mostly based on electricity, natural gas, and fossil fuels) in SGs is a common way to enhance inside temperature and improve crop production during the cold winter period [22-24]. However, this may increase the operation cost and sometimes produces hazardous gases, for example $\mathrm{CO}_{2}, \mathrm{SO}_{2}$, and $\mathrm{N}_{X} \mathrm{O}$ [23]. Emission of these gases not only increases the air pollution, but also enhances climate change $[25,26]$. Therefore, the use of the SSG could provide an alternative for growers in regions like north China, USA, Canada, and Europe [19,21-24,27,28], which allows crop cultivation in cold periods without using extra heating systems and the associated emission of hazardous gases.

Therefore, this study was aimed at investigating the microclimate and evaluating the evapotranspiration in a sunken solar greenhouse in which cucumber is grown. The results of this study may help farmers choosing the right crops and irrigation practices to achieve substantial economic benefits in sunken solar greenhouses. 


\section{Material and Methods}

\subsection{Experimental Site}

A five year experiment, including three full-year seasons (FY season; October-June/July), two autumn-winter seasons (AW season; August-December/January), and two spring-summer seasons (SS season; February-July), was done in Xinmi city ( $\left.34^{\circ} 27^{\prime} 3.5^{\prime \prime} \mathrm{N}, 113^{\circ} 31^{\prime} 58.5^{\prime \prime} \mathrm{E}\right)$, Henan province, China. The climate in the research region is semi-humid. The annual mean temperature is $14.7^{\circ} \mathrm{C}$ and the total yearly sunshine duration is $1870 \mathrm{~h}$. The mean total yearly rainfall is $542 \mathrm{~mm}$, from which more than $70 \%$ occurs from June to August. The soil type in the study region is silty loam (based on the American soil type standard). Physical and chemical properties of soil in the SSG were measured in the laboratory, excluding field capacity that was measured in situ. Soil properties in this region are nearly uniform in the upper $100 \mathrm{~cm}$ soil layer, with the percentages of clay, silt, and sand of 6-7\%, $64-74 \%$, and 19-29\%, respectively (Table 1). The soil chemical characteristics in the upper $100 \mathrm{~cm}$ are listed in Table 2.

Table 1. Soil texture and hydraulic characteristics in the upper $100 \mathrm{~cm}$ soil layer.

\begin{tabular}{ccccccc}
\hline Depth & $\begin{array}{c}\text { Clay } \\
\mathbf{( \% )}\end{array}$ & $\begin{array}{c}\text { Silt } \\
\mathbf{( \% )}\end{array}$ & $\begin{array}{c}\text { Sand } \\
\mathbf{( \% )}\end{array}$ & Texture & $\begin{array}{c}\text { Field Capacity \# } \\
\mathbf{c m}^{\mathbf{3}} \mathbf{~ c m}^{-\mathbf{3}}\end{array}$ & $\begin{array}{c}\text { Bulk Density \# } \\
\mathbf{g ~ c m}^{-3}\end{array}$ \\
\hline $0-20$ & 6.17 & 64.2 & 29.6 & Silty loam & 0.372 & 1.36 \\
$20-40$ & 6.99 & 74.2 & 18.8 & Silty loam & 0.352 & 1.38 \\
$40-60$ & 6.34 & 71.0 & 22.6 & Silty loam & 0.378 & 1.42 \\
$60-80$ & 7.18 & 70.6 & 22.2 & Silty loam & 0.379 & 1.43 \\
$80-100$ & 6.60 & 67.7 & 25.7 & Silty loam & 0.385 & 1.42 \\
\hline
\end{tabular}

* Soil particle size distribution was measured using the Laser Particle Size Analyzer (Malvern Masterizer 2000, Malvern, Worcestershire, UK); \# Field capacity and bulk density were measured in situ using the traditional Cutting ring method.

Table 2. Soil chemical characteristics in the upper $100 \mathrm{~cm}$ soil layer.

\begin{tabular}{|c|c|c|c|c|c|c|}
\hline $\begin{array}{l}\text { Depth } \\
\text { cm }\end{array}$ & $\begin{array}{c}\text { Organic * } \\
\mathrm{g} \mathrm{kg}^{-1}\end{array}$ & $\begin{array}{c}\text { Total N } \\
\%\end{array}$ & $\begin{array}{l}\mathrm{NO}_{3}-\mathrm{N}^{*} \\
\mathrm{mg} \mathrm{kg}^{-1}\end{array}$ & $\begin{array}{l}\text { Available } P^{*} \\
\text { mg kg }^{* 1}\end{array}$ & $\begin{array}{l}\text { Available } \mathrm{K}^{*} \\
\mathrm{mg} \mathrm{kg}^{-1}\end{array}$ & $\mathrm{pH}^{*}$ \\
\hline $0-20$ & 14.29 & 0.77 & 40.32 & 25.76 & 192.9 & 7.96 \\
\hline $20-40$ & 7.05 & 0.46 & 13.99 & 4.96 & 101.7 & 8.10 \\
\hline $40-60$ & 8.14 & 0.48 & 21.82 & 2.25 & 110.2 & 8.16 \\
\hline $60-80$ & 7.83 & 0.46 & 18.64 & 1.31 & 96.8 & 8.21 \\
\hline 80-100 & 6.38 & 0.46 & 12.42 & 0.59 & 95.4 & 8.18 \\
\hline \multicolumn{7}{|c|}{$\begin{array}{l}\text { * Organic matter content was measured by the vitriol acid-potassium dichromate oxidation method; total } \\
\text { nitrogen in soil was measured by Dumas Nitrogen analyzer; soil } \mathrm{NO}_{3}-\mathrm{N} \text { was measured using potassium chloride } \\
\text { solution-spectrophotometry method; available P content in soil samples was measured by the sodium hydrogen } \\
\text { carbonate solution-Mo-Sb anti spectrophotometric method; Available } \mathrm{K} \text { in soil samples was measured using the } \\
\text { Flame Atomic Absorption spectrophotometric method; and soil pH was measured using a pH meter (model HI8424, } \\
\text { HANNA, Lynnfield, MA, USA). }\end{array}$} \\
\hline
\end{tabular}

\subsection{Sunken Solar Greenhouse Description}

A new type of solar greenhouse, named the sunken solar greenhouse (SSG), was examined in this study, with inside dimensions of $12 \mathrm{~m}$ in width, $70 \mathrm{~m}$ in length, and a total area of $840 \mathrm{~m}^{2}$. The main changes in this greenhouse compared to the traditional solar greenhouse (SG) are: (1) the soil surface is $1.5 \mathrm{~m}$ deeper than the outside soil surface (this is why this greenhouse is entitled as "sunken"); and (2) the north-facing back wall thickness is $8 \mathrm{~m}$ at the bottom, and $2 \mathrm{~m}$ at the top, much larger than the back wall of the traditional SG which is $0.25-0.6 \mathrm{~m}$ thick. The height of the back wall was $5.8 \mathrm{~m}$ from the inside soil surface to the top of the greenhouse (Figure 1a), and about $4.3 \mathrm{~m}$ from the outside soil surface to the top. The cultivated region of the SSG, which was covered by a $0.1 \mathrm{~mm}$ thick transparent plastic film, was facing the south for collecting solar radiation for plant growth and for heating the greenhouse. When building the greenhouse, the upper $20 \mathrm{~cm}$ soil layer in the original soil surface was 
firstly removed and put nearby, then the soils from 20 to $170 \mathrm{~cm}$ depth were removed and used to build the back wall. Lastly, the soil removed from the upper $20 \mathrm{~cm}$ soil layer was refilled on the lowered greenhouse soil surface. This construction technology aims to keep the same soil chemical conditions and biological communities in the root zone inside the SSG as the original soil outside.
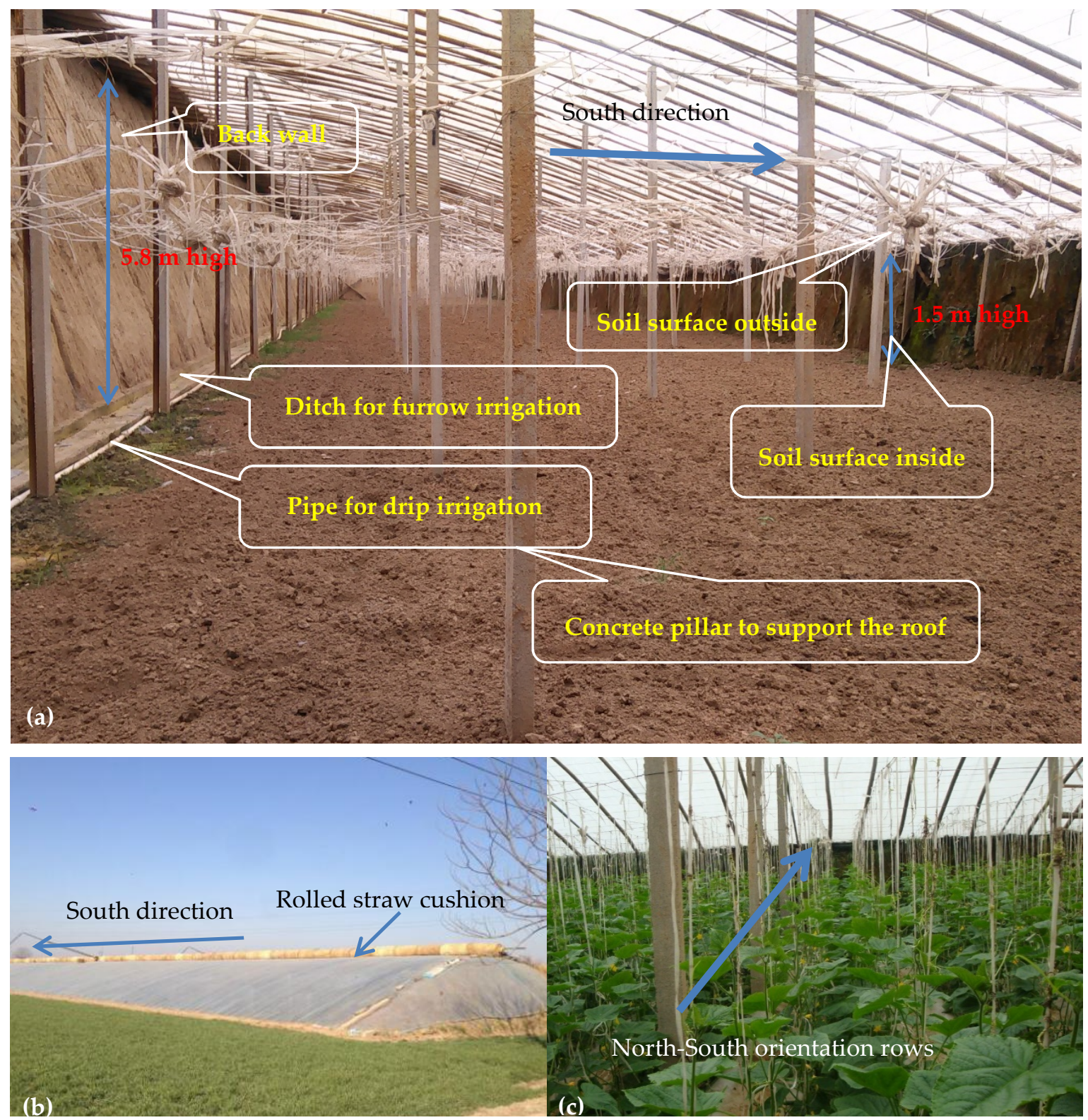

Figure 1. Photos of the sunken solar greenhouse. (a) Inside view of the sunken solar greenhouse pictured just after soil preparation (photo taken on 12 October 2014). (b) Outside view of the sunken solar greenhouse in winter. The front plastic cover is facing south, and the rolled straw cushion is seen on the top of the roof. (c) A view of the cucumber plants inside the sunken solar greenhouse (photo taken on 28 December 2014).

A $0.1 \mathrm{~mm}$ thick polyethylene plastic film covered the top of the greenhouse and was renewed every year during August-September to maintain high radiation transmission (Figure 1b). There was an approximately $1 \mathrm{~m}$ width window at the top of the greenhouse for natural ventilation. The window was adjacent to the back wall and the opening size was controlled manually. Usually, the window was opened when the inside temperature is reaching $25-30^{\circ} \mathrm{C}$ and was closed approximately $1 \mathrm{~h}$ before sunset for reducing nighttime heat loss from the greenhouse. In winter nights, a straw cushion was 
deployed on the plastic cover to reduce heat loss and improve climatic conditions inside the SSG. Otherwise, the cushion was rolled on the top of the roof (Figure 1b).

\subsection{Cucumber Planting and Irrigation Management}

Seven cucumber (Cucumis sativus L., varieties of Boxin 201 in the first six seasons and Boxin 301 in the last season) cultivation seasons are presented in this study, from October 2014 to August 2019. For each season, the specific periods from cucumber transplanting to the final harvest are listed in Table 3. Cucumbers were planted on each side of the North-South furrows with $0.30 \mathrm{~m}$ spacing between plants along the row (Figure 1c). The furrow was $0.80 \mathrm{~m}$ in width and $0.20 \mathrm{~m}$ in depth in the middle of the furrow. The $0.5 \mathrm{~m}$ spacing between furrows was used for field management and fruit harvest. Cucumber shoots were transplanted when they had 3-4 leaves. After transplanting, plants were irrigated with an extensive irrigation amount of approximately $60 \mathrm{~mm}$ to provide enough soil water for shoots standing. In the following one month, the plants were not irrigated, aiming at intense root development. After that, regular irrigation started until the last harvest.

Table 3. Dates of agronomic practices on the seven seasons.

\begin{tabular}{|c|c|c|c|c|c|c|c|}
\hline \multirow{3}{*}{$\begin{array}{l}\text { Agronomic } \\
\text { Practice }\end{array}$} & \multicolumn{7}{|c|}{ Season } \\
\hline & 1st & 2nd & 3rd & 4th & 5th & 6th & 7th \\
\hline & FY* & SS & FY & AW & SS & AW & FY \\
\hline Last harvest & 20 July 2015 & 17 July 2016 & 28 May 2017 & $\begin{array}{l}1 \text { February } \\
2018\end{array}$ & 30 July 2018 & $\begin{array}{c}7 \text { December } \\
2018\end{array}$ & 31 July 2019 \\
\hline Total days & 267 & 153 & 217 & 165 & 173 & 114 & 228 \\
\hline
\end{tabular}

Cucumber plants were drip irrigated during the experimental period. One drip tape was deployed at the middle line of each furrow to irrigate the two neighboring cucumber rows on that furrow. The main irrigation pipe of the drip irrigation system was deployed along the back wall. Irrigation water was firstly drawn from groundwater and then stored in a $10 \mathrm{~m}^{3}$ tank. The head of the drip irrigation system included a pump, flow meter, differential pressure fertilizer tank, filter, valve, and pressure meter. The spacing of drippers was $30 \mathrm{~cm}$, and discharge was $2.31 \mathrm{~h}^{-1}$ under normal irrigation pressure of $0.1-0.15 \mathrm{MPa}$. Drip irrigation started when the soil matric potential reached around $-10--15 \mathrm{kPa}$ as measured using a tensiometer installed at $20 \mathrm{~cm}$ depth. Each irrigation depth was approximately $10 \mathrm{~mm}$; this value was calculated as the water deficit between field capacity and water content when soil matric potential is about $-15 \mathrm{kPa}$ in the upper $30 \mathrm{~cm}$ soil layer.

During the cucumber growth period, stems were banded to wires to support vertical plant growth. When a stem grew to approximately $2 \mathrm{~m}$ in height, it was dropped down and kept at the height of $1 \mathrm{~m}$ above the ground surface to facilitate harvest and leaves' trim. Usually, some leaves in the low part of the stem were trimmed, and only 10-13 leaves were left on the stem to support cucumber plant growth and fruit production. During winter, stem drop took place at one month intervals and during spring and summer at 15-20 day intervals. With this procedure, leaf area index (LAI) was maintained nearly constant in the range 2.0 to 2.6 during the seven experimental periods, which is close to values reported in the literature [29].

Before transplanting, the upper $30 \mathrm{~cm}$ soil layer was plowed with fertilizers' application. The base application of fertilizers included $200 \mathrm{~m}^{3} \mathrm{ha}^{-1}$ of organic fertilizer (a mixture of chicken manure and wheat straw), $1200 \mathrm{~kg} \mathrm{ha}^{-1}$ of calcium superphosphate, and $1050 \mathrm{~kg} \mathrm{ha}^{-1}$ of quick lime. Nitrogen was applied through the drip-fertigation system at approximately $4.5 \mathrm{~kg} \mathrm{ha}^{-1} \mathrm{day}^{-1}$. Soil surface was covered with a $0.015 \mathrm{~mm}$ thickness black plastic film to minimize soil evaporation and grass growth during all growth periods. 


\subsection{Measurements}

Microclimatic variables, including solar radiation, air temperature and humidity, and wind speed both inside and outside of the greenhouse, were sampled at $30 \mathrm{~s}$ intervals, and $30 \mathrm{~min}$ averages were recorded. An internal climate station was positioned at the greenhouse center, at $2.5 \mathrm{~m}$ height above the soil surface and the external one was deployed at $1 \mathrm{~m}$ above the greenhouse top. The radiation (Model: TBQ-2) and wind speed sensors (Model: EC-9S) were from Jinzhou Sunshine Technology Co. Ltd., China. Air temperature and humidity sensors (Model: HMP60) were from Vaisala Co. (Helsinki, Finland), and data loggers were CR1000 from Campbell Scientific Inc. (Logan, UT, USA). In the first five seasons, the inside air velocity was measured with a three-cup anemometer (Model: EC-9S, Jinzhou Sunshine Technology Co. Ltd., Jinzhou, Liaoning, China). With this sensor, and due to its threshold velocity $\left(0.5 \mathrm{~m} \mathrm{~s}^{-1}\right)$ and low resolution $\left(0.1 \mathrm{~m} \mathrm{~s}^{-1}\right)$, most recorded air velocity values were zero. Therefore, in the last two seasons, the inside air velocity was measured with an ultrasonic anemometer with threshold velocity $0.01 \mathrm{~m} \mathrm{~s}^{-1}$ and measurement resolution of $0.1 \mathrm{~m} \mathrm{~s}^{-1}$ (Model: ATMOS 22, METER Group Inc., Pullman, WA, USA); data were sampled at 1 min intervals, and $10 \mathrm{~min}$ averages were recorded using an EM50 data logger (Dynamax Inc., Houston, TX, USA).

Soil temperatures inside the greenhouse were measured using T-type thermocouples positioned at the soil surface, and at 0.10 and $0.20 \mathrm{~m}$ depths near plant stems from 18 October 2018 to 31 July 2019. Data were sampled at $30 \mathrm{~s}$ intervals, and $30 \mathrm{~min}$ mean values were recorded by a CR1000 data logger.

The farmer recorded cucumber yield in three selected rows, and the price of cucumber fruits was recorded every marketing. Yield and revenue per hectare were estimated on a seasonal basis.

\subsection{Reference Crop Evapotranspiration Calculation}

Reference crop evapotranspiration outside and inside the SSG $\left(\mathrm{ET}_{\mathrm{o}, \mathrm{out}}, \mathrm{ET}_{\mathrm{o}, \mathrm{in}}\right.$, respectively) were calculated using the FAO56 Penman-Monteith (PM) method [30]. Inside greenhouses, $\mathrm{ET}_{\mathrm{o}, \text { in }}$ calculated by the PM method is usually underestimated because of the low wind speed $\left(0.01-0.2 \mathrm{~m} \mathrm{~s}^{-1}\right)$, which can result in a considerably high aerodynamic resistance and a too small $\mathrm{ET}_{\mathrm{o}, \mathrm{in}}$ [31]. Therefore, in this study, an adjusted Penman-Monteith method developed by Fernández et al. in papers [31,32] was employed to calculate inside $\mathrm{ET}_{\mathrm{o} \text {,in }}$ (see Equation (2) below) where a fixed aerodynamic resistance of $295 \mathrm{~s} \mathrm{~m}^{-1}$ is used. The calculation methods are given as:

$$
\begin{gathered}
E T_{\mathrm{o}, \text { out }}=\frac{0.408 \Delta R_{n}-G+\gamma \frac{900}{T+273} u_{2} V P D}{\Delta+\gamma\left(1+0.34 u_{2}\right)}, \\
E T_{\mathrm{o}, \text { in }}=\frac{0.408 \Delta R_{n}-G+\gamma \frac{628}{T+273} V P D}{\Delta+1.24 \gamma},
\end{gathered}
$$

where $E T_{\mathrm{o} \text {,out }}$ and $E T_{\mathrm{o} \text {,in }}$ are the daily reference crop evapotranspiration in open field and inside the greenhouse, respectively $\left(\mathrm{mm} \mathrm{day}^{-1}\right) ; G$ is the soil heat flux $\left(\mathrm{MJ} \mathrm{m}^{-2} \cdot\right.$ day $\left.^{-1}\right)$, which can be neglected at daily intervals [30]; $\gamma$ is the psychrometric constant $\left(\mathrm{kPa}^{\circ} \mathrm{C}^{-1}\right) ; u_{2}$ is the wind speed measured at $2 \mathrm{~m}$ above the ground surface outside the greenhouse $\left(\mathrm{m} \mathrm{s}^{-1}\right) ; V P D$ is the vapor pressure deficit which is the difference between the saturation and actual vapor pressure $(\mathrm{kPa})$, and $\Delta$ is the slope of the saturation vapor pressure curve at a given air temperature $\left(\mathrm{kPa}^{\circ} \mathrm{C}^{-1}\right) . R_{n}$ is the net radiation (MJ $\mathrm{m}^{-2}$. day ${ }^{-1}$ ), estimated using measured solar radiation, maximum and minimum temperatures, and relative humidity following Allen et al. [30]. The calculation equation is as following:

$$
R_{n}=R_{n s}-R_{n l}
$$

where $R_{n s}$ is the net shortwave radiation ( $\left(\mathrm{MJ} \mathrm{m}{ }^{-2}\right.$ day $^{-1}$ ). The reflection coefficient (albedo) of the hypothetical grass reference crop is chosen as 0.23 , resulting with:

$$
R_{n s}=(1-0.23) R_{s}
$$





Allen et al. [30]:

$$
R_{n l}=\sigma\left[\frac{T_{\max , K^{4}+T_{\min , K^{4}}}}{2}\right]\left(0.34-0.14 \sqrt{e_{a}}\right)\left(1.35 \frac{R_{s}}{R_{s o}}-0.35\right)
$$

where $\sigma$ is the Stefan-Boltzmann constant $\left(4.90310^{-9} \mathrm{MJ} \mathrm{K}^{-4} \mathrm{~m}^{-2}\right.$ day $\left.{ }^{-1}\right) ; T_{\max , \mathrm{K}}$ is the daily maximum absolute temperature (K); $T_{\min , K}$ is the daily minimum absolute temperature $(\mathrm{K}) ; e_{a}$ is the actual vapor pressure (kPa); $R_{S} / R s_{0}$ is the relative shortwave radiation $(\leq 1) ; R_{S}$ is measured solar radiation (MJ $\mathrm{m}^{-2}$ day $\left.^{-1}\right)$; and $R_{s o}$ is the clear-sky radiation $\left(\mathrm{MJ} \mathrm{m}^{-2}\right.$ day $\left.^{-1}\right)$ and is a constant for a given site and specific day. The $R_{s o}$ was estimated by the latitude $\left(34^{\circ} 27^{\prime} 3.5^{\prime \prime} \mathrm{N}\right)$, longitude $\left(113^{\circ} 31^{\prime} 58.5^{\prime \prime} \mathrm{E}\right)$, and the elevation above sea level $(110.4 \mathrm{~m})$ at the experimental site for each day of a year, using the method by Allen et al. [30].

Hourly crop evapotranspiration $\left(\mathrm{ET}_{\mathrm{c}, \mathrm{hr}}, \mathrm{mm} \mathrm{h}^{-1}\right)$ under conditions of sufficient soil water can be estimated by the Penman-Monteith equation:

$$
\lambda E T_{c, h r}=\frac{1000}{\rho_{H 2 O}} \frac{\Delta R_{n, h r}-G_{h r}+3600 \rho_{a} C_{p} \frac{V P D_{h r}}{r_{a}}}{\Delta+\gamma\left(1+\frac{r_{s}}{r_{a}}\right)},
$$

where $R_{n, h r}, G_{h r}$, and $V P D_{h r}$ are hourly net radiation $\left(\mathrm{MJ} \mathrm{m}^{-2} \mathrm{~h}^{-1}\right)$, soil heat flux $\left(\left(\mathrm{MJ} \mathrm{m}^{-2} \mathrm{~h}^{-1}\right)\right.$, and hourly mean vapor pressure deficit $(\mathrm{kPa})$, respectively. Hourly soil heat flux is taken as $10 \%$ of the corresponding hourly net radiation following [30]. $\gamma$ is the psychrometric constant $\left(\mathrm{kPa}^{\circ} \mathrm{C}^{-1}\right)$; and $\Delta$ is the slope of the saturation vapor pressure curve at hourly mean air temperature $\left(\mathrm{kPa}^{\circ} \mathrm{C}^{-1}\right) \cdot \rho_{a}$ is the mean air density given as $1.293 \mathrm{~kg} \mathrm{~m}^{-3} ; \mathrm{C}_{\mathrm{p}}$ is the specific heat of the air at constant pressure equal to $1.03 \times 10^{-3} \mathrm{MJ} \mathrm{kg}^{-1}{ }^{\circ} \mathrm{C}^{-1} ; \lambda$ is the latent heat of vaporization equal to $2.45 \mathrm{MJ} \mathrm{kg}^{-1} \cdot \rho_{\mathrm{H} 2 \mathrm{O}}$ is the pure water density $\left(10^{3} \mathrm{~kg} \mathrm{~m}^{-3}\right)$. The constant of 1000 in the right side of Equation (6) is unit conversion from meter to millimeter, and 3600 is time unit conversion from second to hour. The $r_{s}$ is the (bulk) surface resistance that can be estimated as $r_{s}=r_{l} /(0.5 L A I)$, where LAI is leaf area index, and $r_{l}$ is bulk stomatal resistance of a well-illuminated leaf $\left(\mathrm{s} \mathrm{m}^{-1}\right)$. For greenhouse cucumber, Yang et al. [33] found that stomatal resistance $r_{l}$ is exponentially related to solar radiation $\left(R_{s}, \mathrm{~W} \mathrm{~m}^{-2}\right)$ as $r_{l}=142.7+953.9 \exp \left(-0.0081 \times R_{s}\right)$, a relation confirmed in other studies on greenhouse cucumber by Huang et al. [34] and Yan et al. [35]. Therefore, measured hourly $R_{s}$ was used to estimate hourly $r_{s}$ using the equation developed by Yang et al. [33]. $r_{a}$ is the aerodynamic resistance, estimated using inside measured air velocity and wind sensor height following the method by Allen et al. [30]. Since inside air velocity was only measured during the last two seasons, a mean value of $0.1 \mathrm{~m} \mathrm{~s}^{-1}$ was used in the other five seasons.

The hourly inside $R_{\mathrm{n}}$ was estimated from internal hourly $R_{s}$. First, based on the daily measured inside $R_{s}$ and estimated daily $R_{n}$ using Equations (3)-(5), inside daily $R_{n}$ was found to be linearly related to daily $R_{s}$ with a slope of $0.676\left(R^{2}=0.905\right)$ when all daily data $(\mathrm{n}=1685)$ of the seven seasons were pooled together. This relation is close to the result of Chen et al. [36]. They found that net radiation can be estimated by $R_{n}=0.86(1-\operatorname{Exp}(-0.7 L A I)) R_{s}$. Taking the leaf area index of the present study as $L A I=2.3$, this relationship can be expressed as $R_{n}=0.688 R_{S}$, which is much closer to the slope of 0.676 in this study. Therefore, the hourly inside $R_{n}$ was estimated from inside measured hourly $R_{S}$ as $R_{n}=0.676 R_{s}$.

Therefore, in the present study, all variables in Equation (6) were taken at hourly time points to calculate hourly $\mathrm{ET}_{\mathrm{c}}$. The daily $\mathrm{ET}_{\mathrm{c}}$ was the sum of all hourly values during the day.

\subsection{Decoupling Coefficient}

The decoupling coefficient $\Omega$ describes the relative contribution of the radiative and aerodynamic terms in the PM equation to the total evapotranspiration. The aerodynamic term prevails when the surface is "coupled" to the ambient weather conditions $(\Omega<0.5)$ [37]. This is the case for a rough 
surface exposed to strong wind and low net radiation [38]. On the other hand, the radiative term prevails when a short well-watered canopy is exposed to bright sunshine, humid air and a light wind; under such conditions, the surface is decoupled from its adjacent environment. The decoupling coefficient, $\Omega$, was calculated as [38,39]:

$$
\Omega=\frac{1+\frac{\Delta}{\gamma}}{1+\frac{\Delta}{\gamma}+\frac{r_{s}}{r_{b}}}
$$

where $r_{b}$ is canopy boundary layer resistance, which depends on the airflow regime over the leaf. The $r_{b}$ was taken after Moller et al. [39] and Liu et al. [37]:

$$
r_{b}=305 \frac{\left(\frac{d}{u}\right)^{0.5}}{L A I}
$$

where $d$ is the characteristic leaf dimension, in $\mathrm{m}, u$ is the measured air velocity at $2.5 \mathrm{~m}$ height within the greenhouse, in $\mathrm{m} \mathrm{s}^{-1}$, and $L A I$ is the leaf area index taken as 2.3 in this study.

Canopy resistance $r_{S}$ is mainly dependent on crop characteristics and climatic conditions. Previous literature shows that crop stomatal resistance inside greenhouses is closely related to inside solar radiation, and for crop transpiration calculation it can be estimated using the measured solar radiation [40,41]. In a research on a solar greenhouse in central China, Yan et al. [42] reported that $r_{s}$ of cucumber plants during daytime varied between $35 \mathrm{~s} \mathrm{~m}^{-1}$ in the spring and $40 \mathrm{~s} \mathrm{~m}^{-1}$ in the autumn seasons. They also found that on average, $r_{s}$ remained relatively constant during daytime and increased in the late afternoon when radiation decreases, and stomata are closed. Huang et al. [34] found that stomatal resistance $\left(r_{l}\right)$ of greenhouse cucumber leaves was about $100 \mathrm{~s} \mathrm{~m}^{-1}$ and the corresponding canopy resistance $r_{s}$ was $50 \mathrm{~s} \mathrm{~m}^{-1}$ when solar radiation was higher than $150 \mathrm{~W} \mathrm{~m}^{-2}$, which is close to $40 \mathrm{~s} \mathrm{~m}^{-1}$ found by Yan et al. [42]. We found that inside solar radiation from 10:00 to 15:00 on sunny days was higher than $150 \mathrm{~W} \mathrm{~m}^{-2}$ such that $r_{s}$ could change slightly during the daytime. Therefore, to calculate the decoupling coefficient in the greenhouse, $r_{s}$ was taken as $40 \mathrm{~s} \mathrm{~m}^{-1}$.

\subsection{Data Analysis}

In this study, a Microsoft Excel template was used to calculate all items and prepare the figures.

\section{Results and Discussion}

\subsection{Fruit Yields and Economic Benefits}

The full year fresh cucumber yield averaged 249 ton ha ${ }^{-1}$ in the 1 st, 3rd, and 7 th seasons, 174 ton $\mathrm{ha}^{-1}$ in the spring-summer of the 2 nd and 5 th seasons, and 97 ton ha ${ }^{-1}$ in autumn-winter of the 4 th and 6th seasons. The yield of 174 ton $\mathrm{ha}^{-1}$ in the SS season was higher than 25-130 ton ha ${ }^{-1}$ reported in the same season in previous studies [43-47], and the yield of 97 ton ha ${ }^{-1}$ in AW season was also higher than 38-86 ton ha ${ }^{-1}$ in the same season reported by Abdalhi et al. [48] and Zhang et al. [43]. The Food and Agriculture Organization (FAO) reported that cucumber (including cucumbers and gherkins) production in 2018 was 56 million ton in China, which accounts for approximately $75 \%$ of world total; and the cucumber production per hectare was 53.8 ton, which was $42 \%$ higher than the world mean yield of 37.9 ton ha ${ }^{-1}$ [49]. The measured yield of 249 ton ha ${ }^{-1}$ at full season in this study was 3.6 and 5.6 times higher than the China and world averages, respectively.

The yearly mean income from cucumber production in this study was recorded 847,000 $\mathrm{RMB} \mathrm{ha}^{-1}$. This income was 21 times higher than the mean income of 39,000 $\mathrm{RMB} \mathrm{ha}^{-1}$ in the agriculture sector of China in 2018 and was 25 times higher than 33,000 RMB ha ${ }^{-1}$ in the wheat-maize rotation system in north China [50]. Hence, cucumber cultivation in the SSG had a good yield and high economic benefit. 


\subsection{Microclimate Inside and Outside of the Sunken Solar Greenhouse}

A summary of monthly mean microclimate variables inside and outside the SSG is shown in Table 4. Generally, inside monthly mean air temperature ranged from 16.3 to $31.6^{\circ} \mathrm{C}$, however, they were from 1.7 to $29.1{ }^{\circ} \mathrm{C}$ outside the SSG. A much high inside temperature $\left(16.3-18.2^{\circ} \mathrm{C}\right.$ on average) in winter shows inside temperature was obviously improved. Inside solar radiation decreased greatly because of the top covering. Inside humidity was higher than that outside. In winter, monthly mean humidity could reach $90 \%$ in January and was $>85 \%$ from November to February. Both inside temperature and humidity increasing finally resulted in the inside vapor pressure deficit decreasing. Inside air velocity ranged from 0.06 to $0.1 \mathrm{~m} \mathrm{~s}^{-1}$, however it was from 1.17 to $1.6 \mathrm{~m} \mathrm{~s}^{-1}$. This shows inside air velocity decreased greatly. Inside monthly mean $\mathrm{ET}_{\mathrm{o}}$ ranged from 0.81 to $2.77 \mathrm{~mm}^{-1} \mathrm{day}^{-1}$ with mean of $1.76 \mathrm{~mm} \mathrm{day}^{-1}$, however that outside was from 0.85 to $3.96 \mathrm{~mm}^{-1 a y}{ }^{-1}$ with mean of $2.30 \mathrm{~mm} \mathrm{day}^{-1}$, indicating an $\mathrm{ET}_{\mathrm{o}}$ decreased inside the SSG, From the data in Table 4, we see the inside microclimate in this SSG was greatly improved. The change characteristics of each microclimate variable inside SSG were detailed in the following text. 
Table 4. Summary of the monthly mean climate condition, mean $\left(\mathrm{T}_{\mathrm{ave}}\right)$, maximum $\left(\mathrm{T}_{\max }\right)$ and minimum $\left(\mathrm{T}_{\min }\right)$ daily temperatures, daily solar radiation $\left(\mathrm{R}_{\mathrm{s}}\right)$, relative



\begin{tabular}{|c|c|c|c|c|c|c|c|c|c|}
\hline \multirow{2}{*}{ Month } & \multirow{2}{*}{ Location } & $T_{\text {ave }}$ & $\mathrm{T}_{\max }$ & $\mathbf{T}_{\min }$ & $\mathbf{R}_{\mathrm{s}}$ & RH & Wind & VPD & $\mathbf{E T}_{\mathbf{o}}$ \\
\hline & & ${ }^{\circ} \mathrm{C}$ & ${ }^{\circ} \mathrm{C}$ & ${ }^{\circ} \mathrm{C}$ & MJ m ${ }^{-2}$ day $^{-1}$ & $\%$ & $\mathrm{~s} \mathrm{~m}^{-1}$ & $\mathbf{k P a}$ & $\mathrm{mm}$ day $^{-1}$ \\
\hline \multirow{2}{*}{ September \# } & Outside & $22.79 \pm 0.98$ & $28.06 \pm 0.91$ & $18.23 \pm 1.04$ & $10.73 \pm 2.58$ & $72.97 \pm 9.73$ & $1.17 \pm 0.52$ & $0.78 \pm 0.32$ & $2.40 \pm 0.43$ \\
\hline & Inside & $23.62 \pm 2.22$ & $33.15 \pm 4.53$ & $17.58 \pm 2.36$ & $6.18 \pm 0.94$ & $76.77 \pm 5.42$ & N.M * & $0.71 \pm 0.16$ & $1.71 \pm 0.23$ \\
\hline \multirow{2}{*}{ October } & Outside & $16.37 \pm 0.98$ & $21.62 \pm 2.19$ & $11.91 \pm 1.29$ & $8.60 \pm 2.89$ & $72.40 \pm 11.99$ & $1.36 \pm 0.58$ & $0.55 \pm 0.25$ & $1.67 \pm 0.54$ \\
\hline & Inside & $19.77 \pm 1.78$ & $31.12 \pm 5.72$ & $13.52 \pm 1.06$ & $6.38 \pm 2.33$ & $79.43 \pm 10.91$ & N.M & $0.50 \pm 0.26$ & $1.47 \pm 0.48$ \\
\hline \multirow{2}{*}{ November } & Outside & $8.53 \pm 1.33$ & $13.63 \pm 2.63$ & $4.25 \pm 0.08$ & $6.49 \pm 1.18$ & $76.21 \pm 11.41$ & $1.19 \pm 0.32$ & $0.28 \pm 0.14$ & $0.85 \pm 0.16$ \\
\hline & Inside & $16.38 \pm 1.81$ & $25.09 \pm 3.86$ & $11.98 \pm 1.18$ & $4.10 \pm 0.88$ & $86.81 \pm 1.50$ & N.M & $0.26 \pm 0.06$ & $0.88 \pm 0.13$ \\
\hline \multirow[b]{2}{*}{ December } & Outside & $3.90 \pm 1.45$ & $9.19 \pm 2.03$ & $-0.86 \pm 1.32$ & $5.79 \pm 1.00$ & $63.95 \pm 9.97$ & $1.30 \pm 0.37$ & $0.30 \pm 0.08$ & $0.93 \pm 0.21$ \\
\hline & Inside & $17.01 \pm 0.61$ & $25.27 \pm 1.39$ & $13.07 \pm 0.93$ & $3.37 \pm 0.48$ & $89.34 \pm 2.80$ & $0.09 \pm 0.02$ & $0.22 \pm 0.06$ & $0.81 \pm 0.05$ \\
\hline \multirow{2}{*}{ January } & Outside & $1.68 \pm 1.42$ & $6.79 \pm 1.72$ & $-3.10 \pm 1.30$ & $6.06 \pm 0.80$ & $64.29 \pm 4.37$ & $1.33 \pm 0.31$ & $0.26 \pm 0.05$ & $0.90 \pm 0.14$ \\
\hline & Inside & $16.34 \pm 0.87$ & $24.69 \pm 0.71$ & $12.46 \pm 1.21$ & $3.83 \pm 0.66$ & $90.54 \pm 4.44$ & $0.06 \pm 0.01$ & $0.19 \pm 0.09$ & $0.86 \pm 0.08$ \\
\hline \multirow{2}{*}{ February } & Outside & $4.76 \pm 1.48$ & $10.87 \pm 2.29$ & $-0.97 \pm 1.01$ & $8.85 \pm 1.30$ & $59.76 \pm 7.03$ & $1.41 \pm 0.47$ & $0.36 \pm 0.08$ & $1.35 \pm 0.32$ \\
\hline & Inside & $18.82 \pm 1.17$ & $28.23 \pm 1.68$ & $13.84 \pm 0.81$ & $5.36 \pm 0.45$ & $86.83 \pm 3.03$ & $0.09 \pm 0.02$ & $0.30 \pm 0.07$ & $1.22 \pm 0.06$ \\
\hline \multirow[b]{2}{*}{ March } & Outside & $11.50 \pm 0.70$ & $17.50 \pm 1.19$ & $5.42 \pm 0.18$ & $11.71 \pm 0.60$ & $59.55 \pm 9.91$ & $1.60 \pm 0.15$ & $0.57 \pm 0.14$ & $2.17 \pm 0.22$ \\
\hline & Inside & $21.40 \pm 0.43$ & $30.22 \pm 1.28$ & $16.64 \pm 0.55$ & $7.46 \pm 1.28$ & $82.83 \pm 4.89$ & $0.10 \pm 0.01$ & $0.45 \pm 0.13$ & $1.74 \pm 0.22$ \\
\hline \multirow{2}{*}{ April } & Outside & $17.41 \pm 1.20$ & $23.19 \pm 1.44$ & $11.40 \pm 1.15$ & $13.72 \pm 1.43$ & $64.98 \pm 7.22$ & $1.59 \pm 0.32$ & $0.74 \pm 0.16$ & $2.86 \pm 0.35$ \\
\hline & Inside & $22.18 \pm 1.18$ & $32.64 \pm 2.22$ & $15.33 \pm 0.67$ & $8.39 \pm 1.42$ & $79.47 \pm 4.06$ & $0.10 \pm 0.02$ & $0.59 \pm 0.14$ & $2.10 \pm 0.02$ \\
\hline \multirow{2}{*}{ May } & Outside & $22.17 \pm 1.18$ & $28.25 \pm 1.69$ & $15.85 \pm 1.33$ & $16.40 \pm 2.03$ & $61.77 \pm 10.07$ & $1.52 \pm 0.16$ & $1.07 \pm 0.32$ & $3.66 \pm 0.48$ \\
\hline & Inside & $25.13 \pm 1.13$ & $36.51 \pm 2.17$ & $17.39 \pm 1.30$ & $10.29 \pm 1.88$ & $71.93 \pm 7.84$ & $0.10 \pm 0.02$ & $0.93 \pm 0.27$ & $2.71 \pm 0.41$ \\
\hline \multirow{2}{*}{ June } & Outside & $26.93 \pm 0.71$ & $32.88 \pm 1.10$ & $21.32 \pm 0.72$ & $15.83 \pm 2.92$ & $63.84 \pm 6.74$ & $1.38 \pm 0.33$ & $1.34 \pm 0.28$ & $3.96 \pm 0.28$ \\
\hline & Inside & $28.17 \pm 1.70$ & $39.05 \pm 3.32$ & $20.22 \pm 1.90$ & $9.90 \pm 2.48$ & $71.63 \pm 7.51$ & $0.10 \pm 0.02$ & $1.13 \pm 0.36$ & $2.77 \pm 0.58$ \\
\hline \multirow{2}{*}{ July } & Outside & $29.08 \pm 1.07$ & $34.40 \pm 1.64$ & $24.37 \pm 1.05$ & $14.60 \pm 2.41$ & $74.41 \pm 6.89$ & $1.45 \pm 0.26$ & $1.06 \pm 0.25$ & $3.66 \pm 0.50$ \\
\hline & Inside & $31.18 \pm 2.62$ & $43.21 \pm 5.30$ & $21.88 \pm 3.15$ & $8.78 \pm 2.85$ & $78.46 \pm 9.33$ & $0.11 \pm 0.02$ & $1.00 \pm 0.46$ & $2.45 \pm 0.83$ \\
\hline \multirow{2}{*}{ August } & Outside & $27.53 \pm 0.59$ & $32.49 \pm 0.94$ & $23.58 \pm 0.75$ & $13.20 \pm 2.92$ & $79.38 \pm 3.97$ & $1.37 \pm 0.51$ & $0.77 \pm 0.12$ & $3.14 \pm 0.43$ \\
\hline & Inside & $31.58 \pm 4.35$ & $43.59 \pm 8.91$ & $23.96 \pm 0.98$ & $8.70 \pm 0.63$ & $77.37 \pm 5.15$ & N.M & $1.09 \pm 0.01$ & $2.45 \pm 0.18$ \\
\hline
\end{tabular}

Note: *\# The month begins from September because cucumber season mostly begin from September. Term "N.M" means not measured. 


\subsubsection{Radiation}

Figure 2 shows the daily solar radiation inside and outside during the seven experimental periods (Figure 2a) and the transmissivity of the cover and roof construction elements (Figure 2b). The mean transmissivity in 2014-2015, 2015-2016, 2016-2017, 2017-2018, and 2018-2019 was 0.64, 0.55, 0.55, 0.60, and 0.72 , respectively. It can be seen that the transmissivity somewhat changed with time, which is mainly due to the plastic sheet replacement, plastic material degradation, and dust accumulation on the plastic film. The mean transmissivity over the measurement period, expressed as the slope of the linear regression between inside and outside radiation, was 0.59 (Figure 2c), indicating that more than $40 \%$ of solar energy did not penetrate the greenhouse. Previous studies have reported that the transmissivity of solar greenhouses in north China ranged from 0.60 to 0.70 [9,10], which is close to the present result. The transmissivity range $(0.55-0.72)$ of the present sunken solar greenhouse is also close to that found in India (0.69) [11] as well as to the range of 0.60-0.64 found in Sweden and Netherlands [51].
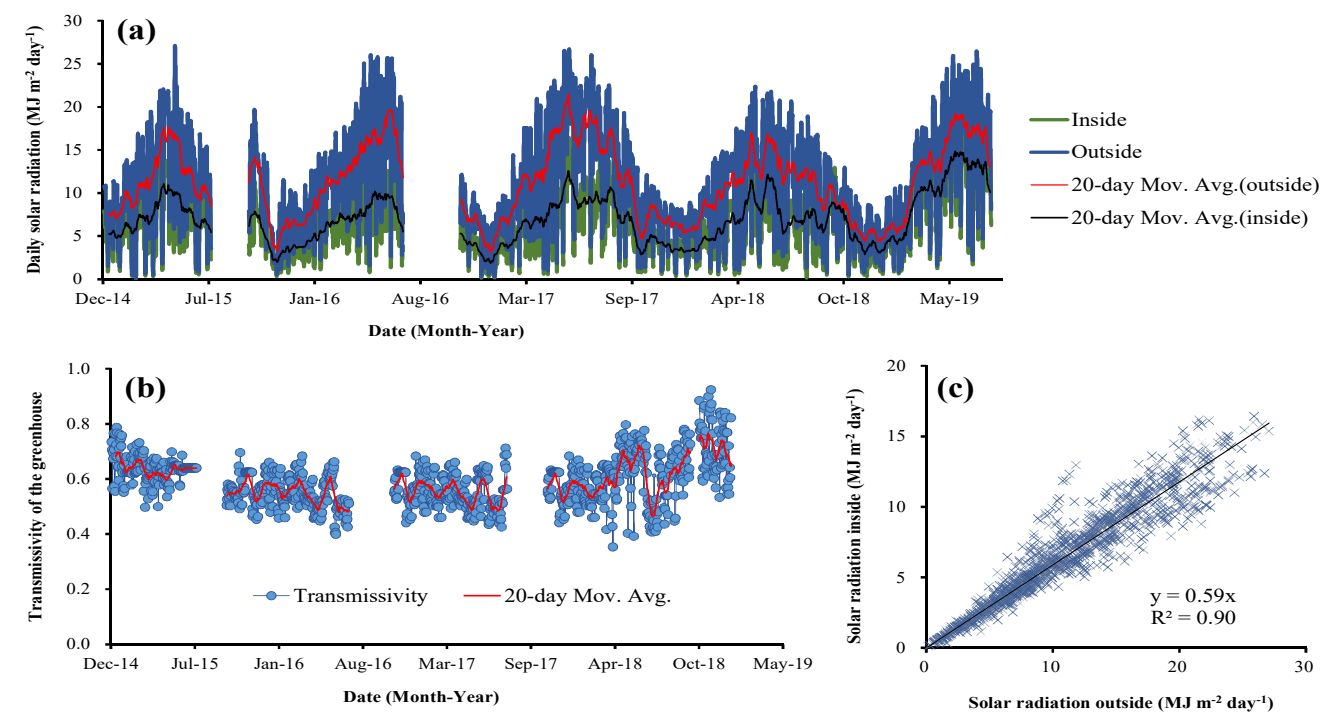

Figure 2. Daily solar radiation inside and outside (a), the daily transmissivity of the sunken solar greenhouse (b), and the relationship between inside and outside solar radiation (c) during the seven seasons. Thin solid black and red lines on (a) represent the 20-day moving average of radiation inside and outside, respectively, and the thin red solid line on (b) represents the 20-day moving average of the greenhouse transmissivity.

\subsubsection{Temperature}

We compared the daily maximum (Figure 3a,b), minimum (Figure 3c,d), and average temperatures (Figure 3e,f) inside and outside of the sunken greenhouse, and results are shown in Figure 3. Generally, the daily maximum temperature inside was higher than $10{ }^{\circ} \mathrm{C}$ (Figure 3a) and increased linearly with that outside (Figure 3b). The daily minimum inside temperature was higher than $5^{\circ} \mathrm{C}$ and also, generally, higher than $10^{\circ} \mathrm{C}$ throughout the seven seasons (Figure 3c). When the daily minimum temperature outside was lower than $10{ }^{\circ} \mathrm{C}$, notably lower than $0{ }^{\circ} \mathrm{C}$ in December and January, the minimum inside temperature generally ranged from 10 to $20^{\circ} \mathrm{C}$ (Figure 3c). When the minimum outside temperature was higher than $10^{\circ} \mathrm{C}$, the minimum inside temperature generally increased with that outside (Figure 3d). The daily average inside temperature was mostly higher than $10^{\circ} \mathrm{C}$ (Figure 3e) and increased with that outside (Figure 3f), similar to the relationship between the maximum temperature inside and outside the SSG. The mean daily temperatures in December, January, and February over the seven seasons are $17.0,16.3$, and $19.0^{\circ} \mathrm{C}$ inside the SSG, respectively, when outside mean temperature ranged from 1.7 to $5.1^{\circ} \mathrm{C}$ in the same period. This inside temperature was close to that of $17.0-17.8^{\circ} \mathrm{C}$ in a fossil-fuel heated greenhouse in January and February in Greece [16]. It was 
also much higher than $10.9-17.1^{\circ} \mathrm{C}$ (from 15 January to 1 May in 2018) observed in a winter greenhouse in north USA, though the latter greenhouse was equipped with a solar heating system [21].


Figure 3. Daily maximum $(\mathbf{a}, \mathbf{b})$, minimum $(\mathbf{c}, \mathbf{d})$, and mean air temperature $(\mathbf{e}, \mathbf{f})$ inside and outside of the sunken solar greenhouse, respectively, during the seven seasons. The black and red thin solid lines on (a,c,e) represent the 20-day moving averages of the corresponding temperatures inside and outside, respectively.

Figure 4 shows the increase of inside daily average, maximum, and minimum temperatures, averaged on each month over the seven seasons, relative to the corresponding outside temperature. The increase in inside temperatures varied with months. The highest increases in daily maximum and minimum temperatures inside the SSG were found in January. They were 17.9 and $15.6^{\circ} \mathrm{C}$, respectively, followed by February $\left(17.4\right.$ and $14.8^{\circ} \mathrm{C}$, respectively) and December $\left(16.1\right.$ and $13.9^{\circ} \mathrm{C}$, respectively). The increases in March dropped to 12.7 and $11.2^{\circ} \mathrm{C}$ for daily maximum and minimum temperature, respectively, and corresponding values in November were 11.5 and $7.7^{\circ} \mathrm{C}$. The increase in temperature decreased substantially from October to September and also from April to June. In June and September, the daily average inside temperatures increased by only $1.2-1.7^{\circ} \mathrm{C}$, indicating a small effect of SSG on temperature during the summer. Figure 4 further shows that the highest increases in temperature are obtained in the months with the lowest outside temperature. In the study region, the lowest monthly mean temperatures outside were found in December, January, and February, and were 3.9, 1.7, and $5.1^{\circ} \mathrm{C}$, respectively. In the same period, the most substantial increase of the inside temperature was 
13.1 $-14.7^{\circ} \mathrm{C}$ for mean, $16.1-17.9^{\circ} \mathrm{C}$ for maximum, and $13.9-14.8^{\circ} \mathrm{C}$ for minimum temperature. The coefficients of variation of the increase in inside maximum and minimum temperatures were $0.03-0.10$ and $0.06-0.18$, respectively, for the period from December to February during the five years (October 2014-July 2019). This small variation shows that the SSG can efficiently and steadily increase inside temperature when the outside temperature is low.

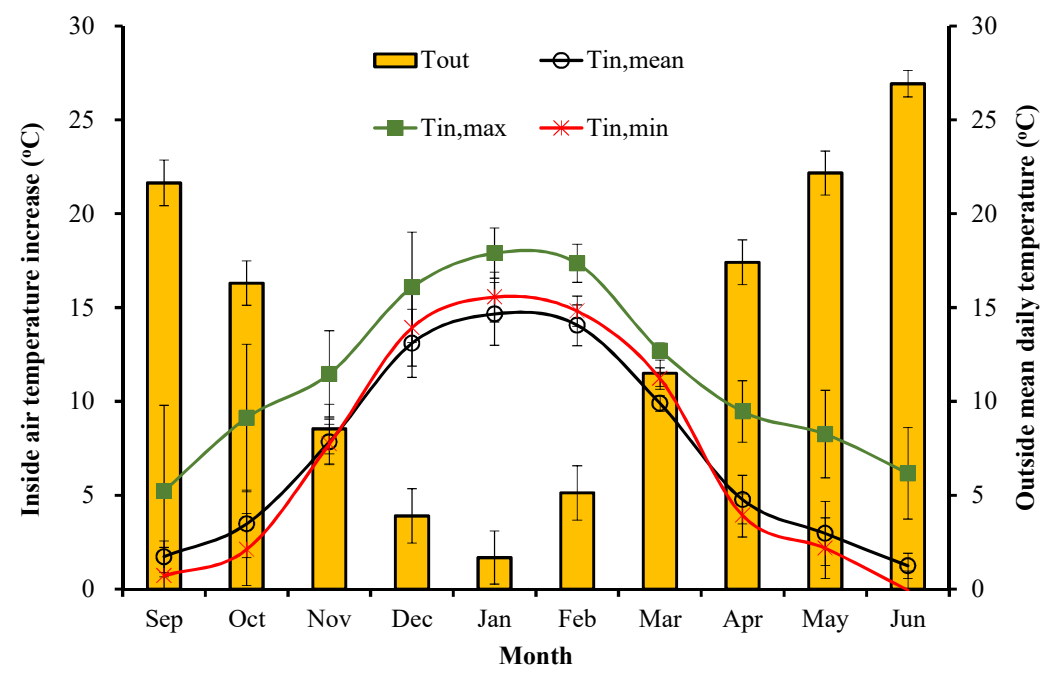

Figure 4. The increase in daily maximum (Tin,max), minimum (Tin,min), and mean (Tin,mean) air temperatures inside and the daily mean temperatures (Tout) outside the sunken solar greenhouse averaged over each month in the seven seasons. Data in July and August are excluded because the greenhouse undergoes high-temperature soil sterilization.

The increase in daily mean temperature in winter (from December to February) observed in the SSG, ranging $5.2-23.4{ }^{\circ} \mathrm{C}$ with a mean of $14.0^{\circ} \mathrm{C}$, was higher than that reported in the literature for the SG. For example, in two traditional SGs in north China [10] the indoor temperature was increased by $10-12.5^{\circ} \mathrm{C}$ in January, and in a multi-span solar greenhouse [9] temperature increases of 10.2 and $6.9^{\circ} \mathrm{C}$ during daytime and nighttime, respectively, were measured in the winter period. Gourdo et al. [14] found that using the passive solar water-sleeve heating system increased the night temperature inside a greenhouse by an average of $2.2^{\circ} \mathrm{C}$ and a maximum of $3.1{ }^{\circ} \mathrm{C}$ when the outside temperature was about $6^{\circ} \mathrm{C}$, which is a lower increase than that in the SSG of this study.

Maintaining air temperature within $20-30{ }^{\circ} \mathrm{C}$ favors cucumber growth and fruit development $[52,53]$. Inside the SSG, during the wintertime (from 1 November to $31 \mathrm{March}$ ), days with maximum temperature in the range $20-30{ }^{\circ} \mathrm{C}$ accounted for $45-57 \%$ of the total days. Days with a maximum temperature higher than $30^{\circ} \mathrm{C}$ accounted for $28-39 \%$ of the entire winter period. Mostly, a maximum temperature higher than $30^{\circ} \mathrm{C}$ lasted less than one hour, and the temperature dropped down quickly below $30^{\circ} \mathrm{C}$ because, under such conditions, natural ventilation was operated by manually opening the roof vent. Therefore, days with a maximum temperature higher than $30^{\circ} \mathrm{C}$ were still in favor of cucumber growth because most of the day the inside temperature was lower than $30{ }^{\circ} \mathrm{C}$. The days with optimal temperatures $\left(>20^{\circ} \mathrm{C}\right)[52,53]$ accounted for $78-90 \%$ of wintertime. Such a temperature regime is much more favorable for cucumber production than that existing in traditional solar greenhouses in north China; hence these SGs cannot be used from December to February.

Cucumber plants might suffer a mild low-temperature disaster if during flowering and fruiting stages inside temperature of $9-14{ }^{\circ} \mathrm{C}$ lasts for $72 \mathrm{~h}$, a moderate disaster when a temperature of $5-10{ }^{\circ} \mathrm{C}$ lasts for $48 \mathrm{~h}$ and a severe disaster for a temperature of $<5^{\circ} \mathrm{C}$ during $24 \mathrm{~h}$ [8]. For traditional SGs in north China, Liang et al. [6] reported that daily mean air temperature from November to December varied between $10-15{ }^{\circ} \mathrm{C}$, with a minimum of $6^{\circ} \mathrm{C}$, which could cause moderate-to-severe low-temperature disaster. Sanchez-Molina et al. [2] reported that a low daily temperature of $5{ }^{\circ} \mathrm{C}$ may cause a severe 
low-temperature disaster for cucumber plants. However, the present results show that in the SSG, monthly mean temperatures ranged from 16.3 to $19.0^{\circ} \mathrm{C}$ during the period from December to January, and the lowest temperature was higher than $10^{\circ} \mathrm{C}$ even when the outside air temperature dropped to $-10{ }^{\circ} \mathrm{C}$. During the seven seasons of the present research, the cucumber plants did not suffer a low-temperature disaster. Hence, the SSG can be used during the cold winter months when the SG is non-operational. In August, the sunken solar greenhouse cannot be used because of the extremely high inside temperature (higher than $40{ }^{\circ} \mathrm{C}$ in sunny days); consequently, this period is always utilized for high-temperature soil sterilization, a common practice also in the traditional SG.

The back wall of the SSG is used for heat storage from solar radiation during daytime and heat release during nighttime when inside temperature drops [54]. The thickness of the back wall is closely related to energy use efficiency as well as inside air temperature [8]. Hassanain et al. [15] reported that in a solar greenhouse, during the daytime, when the wall is heated by solar radiation, the temperature of the inside surface of the back wall is higher than that deep inside the wall, and vice versa during the nighttime or cloudy days, when heat is transferred from the wall to the greenhouse air. A thicker wall has a higher heat capacity so it could store more heat in daytime, and more heat can be released during the night to increase the greenhouse air temperature. For example, Chen et al. [8] reported that increasing SG back wall thickness from 0.5 to $2.05 \mathrm{~m}$ linearly increased the heat-retaining capacity of the solar greenhouse. In the present study, the back wall of the sunken solar greenhouse was $8 \mathrm{~m}$ thick at the bottom and $2 \mathrm{~m}$ at the top, which is much thicker than the normal width of $0.25-0.6 \mathrm{~m} \mathrm{[7-10]}$ in traditional SGs. Hence, the larger temperature increase observed in the SSG, compared with previous reports of the SG, can be partially attributed to the much thicker back wall in the former than in the latter. The low soil surface of the SSG could also reduce heat loss to the outside and may be another reason for the inside temperature being higher than in the SG.

\subsubsection{Relative Humidity and Vapor Pressure Deficit}

Inside relative humidity (RH) averaged $81.1 \%$ over the seven seasons which is suitable for cucumber production [10]; corresponding outside relative humidity was $66.6 \%$. Figure 5 shows the ratio of outside mean daily relative humidity to that inside the SSG during the experiment period. The ratio was mostly lower than 1 , indicating that outside $\mathrm{RH}$ was smaller than that inside. Lower ratios were mostly found in the winter period. Plant transpiration in the SSG was the main reason for higher RH inside. Natural ventilation through the top vent of the SSG could reduce inside RH during the ventilation period, which was generally from 9:00 to 16:00 in sunny days during the winter period; however, it appears that the ventilation rate was not sufficient to decrease inside RH to the level of that outside. High RH in protected environments has been reported in several previous studies $[10,14,37]$.

Daily vapor pressure deficits (VPD) inside and outside the SSG in the five year experimental period are shown in the Figure 6. During a year, both daily VPDs were the lowest in winter, then increased and reached the highest in May and June, and thereafter decreased gradually. Generally, inside daily VPD was lower than outside mainly because of the higher inside RH (Figure 5). Inside VPD was closely related to that outside with a correlation coefficient of 0.78 . When all inside and outside daily VPDs were pooled together, the inside VPD was linearly related to that outside with a slope of 0.86 , indicating $14 \%$ lower inside compared to outside VPD as a whole. It is also confirmed in Table 4, where inside monthly mean VPD ranged from 0.19 to $1.13 \mathrm{kPa}$, however that outside ranged from 0.26 to $1.34 \mathrm{kPa}$. 




Figure 5. The ratio of outside daily mean relative humidity to that inside the sunken solar greenhouse during the seven seasons. Thin solid red line represents the 20-day moving average.

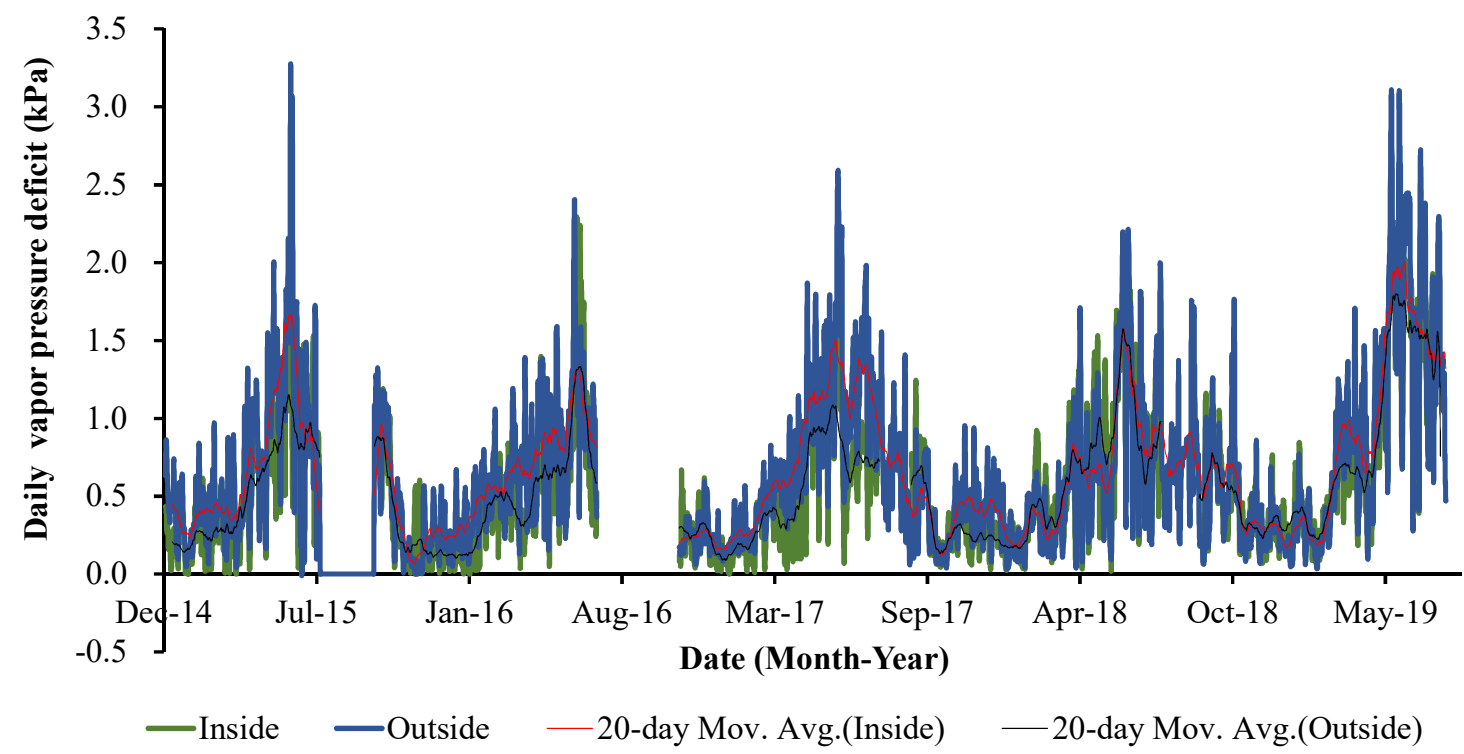

Figure 6. The variation of inside and outside daily vapor pressure deficit (VPD) during the seven seasons. Thin solid lines represent the 20-day moving average of corresponding variables.

\subsubsection{Wind Speed}

During the last two seasons, from 10 December 2018 to 31 July 2019, the air velocity inside the SSG was measured using an ultrasonic anemometer. Results show that the $10 \mathrm{~min}$ average inside air velocity was generally lower than $0.2 \mathrm{~m} \mathrm{~s}^{-1}$ (Figure 7a) though 10 min gusts could reach about $0.6 \mathrm{~m} \mathrm{~s}^{-1}$. There is a clear diurnal curve of the $10 \mathrm{~min}$ mean and gusts of air velocities inside the greenhouse (Figure 7a). Higher air velocity generally occurred from 9:00 to 16:00, with maximum values mostly from 10:00 to 14:00. These relatively high air velocities were closely related to the time of the greenhouse natural ventilation, which was usually from 9:00 to 16:00 in winter. The daily mean inside air velocity was not well correlated to outside wind speed (Figure 7b). Generally, when the wind speed outside was lower than $1.0 \mathrm{~m} \mathrm{~s}^{-1}$, the inside air velocity was low with an average of $0.08 \mathrm{~m} \mathrm{~s}^{-1}$; it averaged $0.1 \mathrm{~m} \mathrm{~s}^{-1}$ when wind speed outside was higher than $1 \mathrm{~m} \mathrm{~s}^{-1}$. Throughout the two seasons, the mean inside air velocity was $0.09 \mathrm{~m} \mathrm{~s}^{-1}$. Similarly, Ni et al. [9] found in two multi-span 
solar greenhouses that inside air velocity ranged from $0.08-0.15 \mathrm{~m} \mathrm{~s}^{-1}$, when outside wind speed varied from $0.51-1.93 \mathrm{~m} \mathrm{~s}^{-1}$. Additionally, Fernández et al. [31] reported that the air velocity inside greenhouse reduced to $0.1-0.3 \mathrm{~m} \mathrm{~s}^{-1}$ when that outside ranged between 1.5 and $3 \mathrm{~m} \mathrm{~s}^{-1}$. Considering the present and previous data, an air velocity of $0.1 \mathrm{~m} \mathrm{~s}^{-1}$ can be considered as a valid typical value in solar greenhouses.
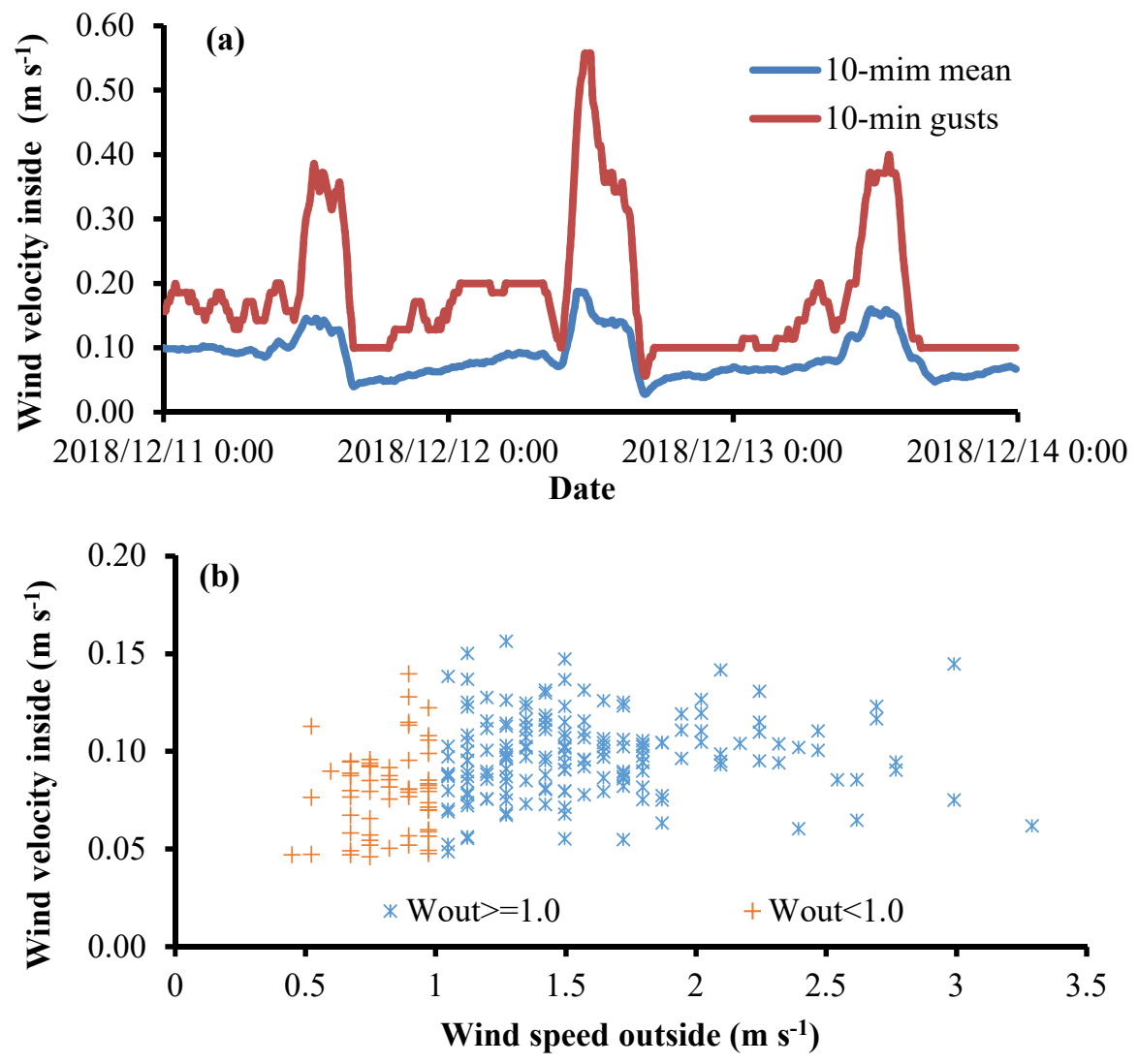

Figure 7. Mean and gust of wind velocity inside the greenhouse (a) and relationship between wind speeds inside and outside (b). Symbols of the brown cross $(+)$ and blue star $\left(^{*}\right)$ on figure (b) indicate outside wind speed (Wout) being lower and higher than $1.0 \mathrm{~m} \mathrm{~s}^{-1}$, respectively.

\subsubsection{Soil Temperature}

Daily maximum, minimum, and mean soil temperatures at the soil surface and 0.1 and $0.2 \mathrm{~m}$ depth were linearly related to the corresponding daily maximum, minimum, and mean air temperatures both inside and outside the greenhouse, with the determination coefficients of the regression lines higher than 0.85 (Figure $8 \mathrm{a}-\mathrm{c}$ ). In particular, the determination coefficient of the regression between the daily mean inside soil temperature at $0 \mathrm{~m}$ and mean air temperature was 0.92 (Figure $8 \mathrm{c}$ ), which is the highest of the regression lines in Figure $8 \mathrm{a}-\mathrm{c}$. Figure $8 \mathrm{~d}$ shows that daily minimum soil temperature at the surface was linearly related to those at 0.1 and $0.2 \mathrm{~m}$ depths with the determination coefficients of the regression lines of 0.99 and 0.97 , respectively. Similar results are also found for the regressions of daily maximum $\left(\mathrm{R}^{2}=0.98\right.$ and 0.96 for 0.1 and $0.2 \mathrm{~m}$ depth, respectively) and mean soil temperatures $\left(R^{2}=0.99\right.$ and 0.98 for 0.1 and $0.2 \mathrm{~m}$ depth, respectively) between the soil surface and at 0.1 and $0.2 \mathrm{~m}$ depth (Supplementary Figure S1). Further, we found that in the greenhouse, daily maximum, minimum, and mean soil temperatures at $0.1 \mathrm{~m}$ depth were the same as those at $0.2 \mathrm{~m}$ depth (Figure 8d). Given the zero intercept, the slopes of the regression lines between the maximum, minimum, and mean soil temperatures at the soil surface to their corresponding temperatures at $0.2 \mathrm{~m}$ depth were $0.99\left(R^{2}=0.99\right), 1.01\left(R^{2}=0.99\right)$, and $0.99\left(R^{2}=0.99\right)$, respectively (Supplementary Figure 
S2), indicating that soil temperature within the main root zone $(0-0.2 \mathrm{~m})$ was uniform, which may improve cucumber growth.


Figure 8. Relationships between daily maximum (a), minimum (b), and mean (c) soil surface temperature to the corresponding daily air temperatures in and out of the sunken solar greenhouse, and the relationships between daily minimum soil temperatures at 10 and $20 \mathrm{~cm}$ depth to those at the soil surface inside the sunken solar greenhouse. Ts,in and Ts,out in regression lines are soil temperatures inside and outside, respectively, and corresponding $x$ (in) and x(out) are inside and outside air temperatures, respectively. Ts,10 and Ts,20 in (d) are soil temperatures at 10 and $20 \mathrm{~cm}$ depth, respectively. 
The minimum soil temperature during winter is a limiting factor for cucumber growth in greenhouses $[8,55]$. Therefore, we roughly estimated the daily minimum outside soil surface temperature using the relationship between soil temperature and air temperature found inside the greenhouse (Figure $8 \mathbf{b}$ ) and measured daily minimum outside air temperature. The results are shown in Figure 9. During the two seasons from 29 October 2018 to 31 July 2019, the daily minimum inside soil surface temperature was higher than $16^{\circ} \mathrm{C}$. The inside minimum soil temperatures, averaged over December, January, and February were 17.2-17.7, 18.3-18.4, and 18.4-18.8 ${ }^{\circ} \mathrm{C}$ at the surface and 0.1 and $0.2 \mathrm{~m}$ depths, respectively. However, the estimated minimum outside soil surface temperature reached nearly zero degrees centigrade $\left(-0.24-0.62{ }^{\circ} \mathrm{C}\right)$ on several days from 29 December 2018 to 2 January 2019. Days with daily minimum outside soil surface temperatures lower than 5 and $10{ }^{\circ} \mathrm{C}$ accounted for $47.8 \%$ and $95.6 \%$ of the period from December to February, respectively (Figure 9). Hence, the greenhouse induced higher inside than outside soil surface temperatures, which avoided the occurrence of the low-temperature disaster. Hodge et al. [21] reported that soil temperature from January to May in a conventional solar greenhouse in north USA ranged $9.3-15.7^{\circ} \mathrm{C}$, which is much less than that $\left(17.2-18.8^{\circ} \mathrm{C}\right)$ measured in winter in the present SSG during the same period. This observation suggests that in winter, the SSG more efficiently utilize solar energy for internal heating than the traditional SG.

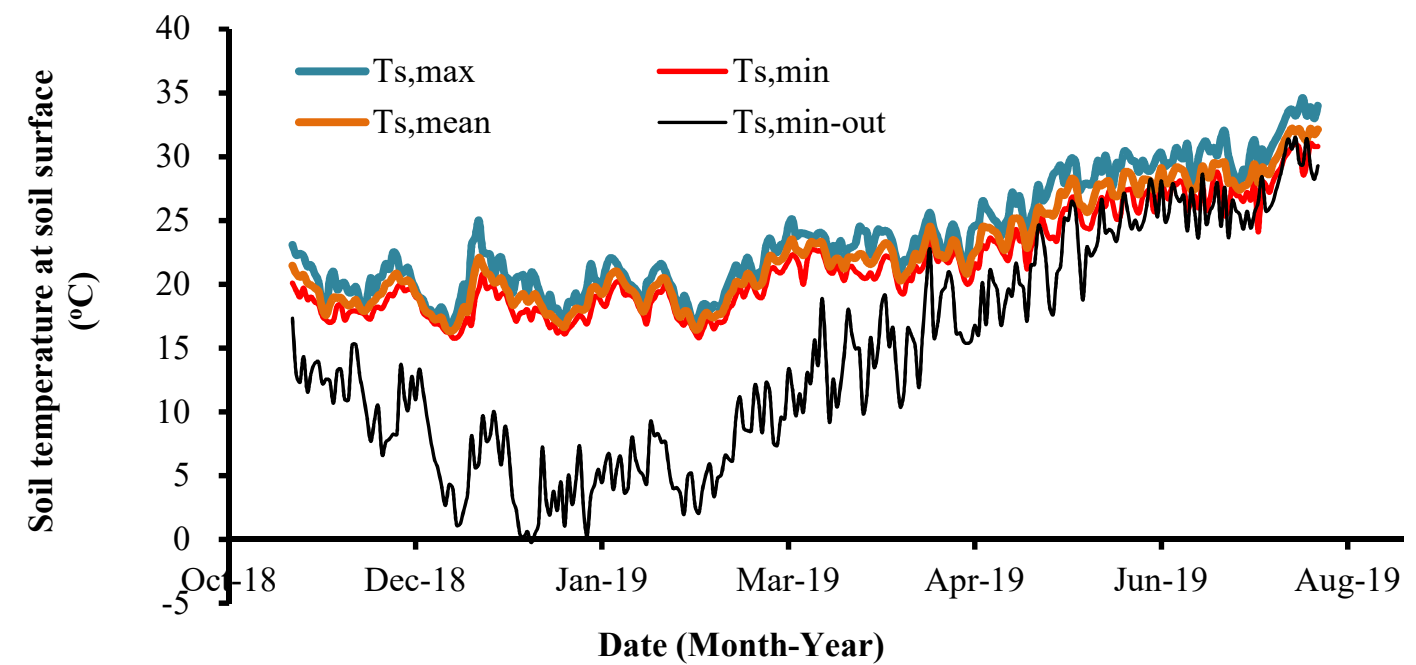

Figure 9. Daily maximum (Ts,max), minimum (Ts,min), and mean (Ts,mean) soil surface temperature inside the sunken solar greenhouse, and the estimated daily minimum outside soil surface temperature (Ts,min-out) from October of 2018 to July of 2019.

\subsection{Decoupling Coefficient}

The effect of the climatic environment on crop evapotranspiration can be evaluated using the decoupling coefficient $(\Omega)$ concept [38] (see Section 2.6). We calculated the daytime (8:00-17:00) decoupling coefficient on three successive sunny days, from 1 to 3 February of 2019 using Equation (7), and results are shown in Figure 10. Generally, $\Omega$ ranged from 0.8 to 0.9 during the daytime. This result indicates that the inside environment is highly decoupled, and the radiative term contributes more than the aerodynamic term to the plant transpiration. Similarly, in pepper and banana screenhouses, daytime $\Omega$ was found to be $0.6-0.8[37,39]$.

The high "decoupling" observed in the SSG is mainly due to the shelter of the plastic film cover and the deeper soil surface, which reduced the air velocity to approximately $0.1 \mathrm{~m} \mathrm{~s}^{-1}$. Lower air velocity causes higher boundary layer resistance, which results in more decoupled conditions (Equation (7)). For example, banana planted in the open field has $\Omega$ of about 0.2 in the daytime, while it is approximately 0.66 inside a shading screenhouse where inside wind velocity is decreased by $80 \%$ [37]. In the present sunken solar greenhouse, when internal air velocity increased from 0.08 to $0.29 \mathrm{~m} \mathrm{~s}^{-1}$ 
from 9:00 to 10:10 on 1 February 2019 (due to natural ventilation), boundary layer resistance decreased from 257 to $135 \mathrm{~s} \mathrm{~m}^{-1}$. Consequently, $\Omega$ decreased from 0.73 to 0.69 (Figure 10). As wind velocity decreased from 0.29 to 0.07 at 11:20, boundary layer resistance increased from 135 to $275 \mathrm{~s} \mathrm{~m}^{-1}$, and consequently, $\Omega$ increased from 0.69 to 0.87 (Figure 10). Similarly, during the daytime on 2 and 3 February 2019, higher air velocity resulted in lower boundary layer resistance and lower $\Omega$.

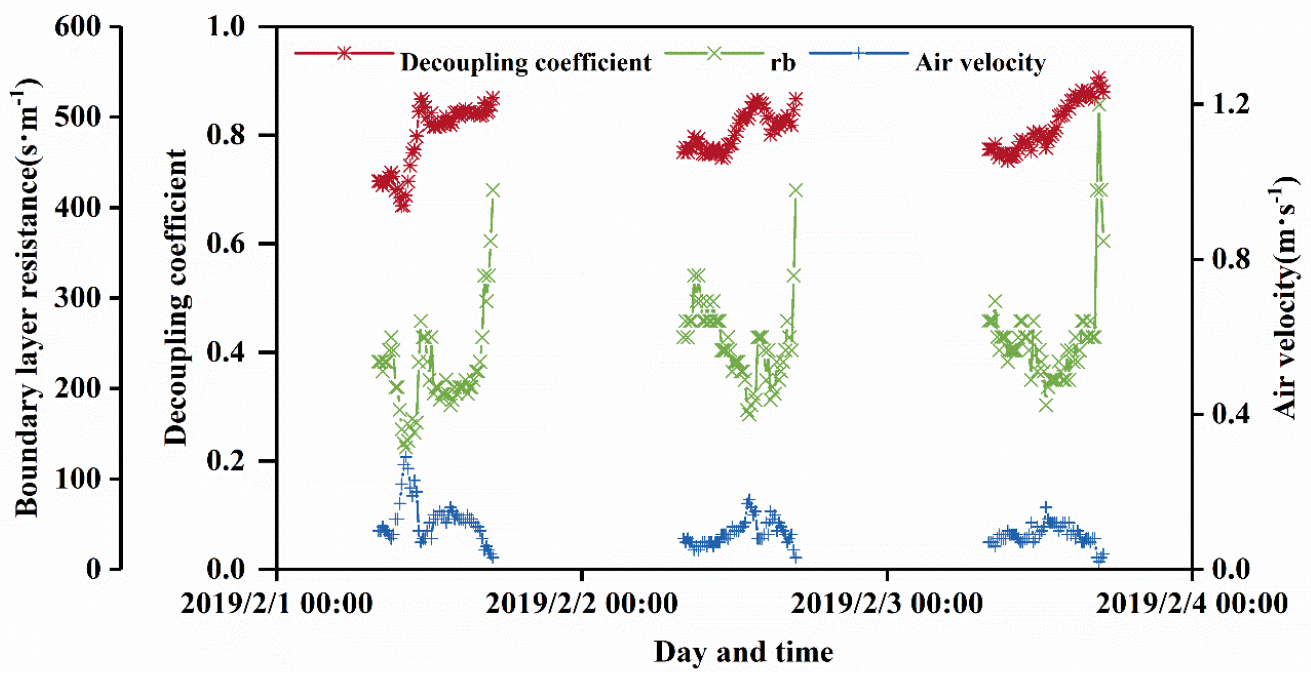

Figure 10. Decoupling coefficient, air velocity and boundary layer resistance during daytime inside the sunken solar greenhouse in three sunny days from 1 to 3 February in 2019.

\subsection{Reference and Crop Evapotranspiration and Influencing Factors}

Figure 11a shows the daily reference crop evapotranspiration inside $\left(\mathrm{ET}_{\mathrm{o}, \mathrm{in}}\right)$ and outside $\left(\mathrm{ET}_{\mathrm{o}, \mathrm{out}}\right)$ the SSG from December 2014 to July 2019. Black and red lines in Figure 11a show corresponding moving averages. Generally, both values increased from March, reached the highest in May and June, then decreased gradually, and had the lowest values from November to January in the following year. Mostly, $\mathrm{ET}_{\mathrm{o} \text {,in }}$ was lower than $\mathrm{ET}_{\mathrm{o}, \mathrm{out}}$. During the winter period (from November to February): $\mathrm{ET}_{\mathrm{o} \text {,in }}$ averaged $0.96 \mathrm{~mm}$ day $^{-1}$, which was significantly $(p<0.05)$ lower than outside $\left(1.05 \mathrm{~mm} \mathrm{day}^{-1}\right)$. However, on May and June, $\mathrm{ET}_{\mathrm{o}, \text { in }}$ was the highest and averaged $2.73 \mathrm{~mm}$ day $^{-1}$, which was lower by $1.07 \mathrm{~mm} \mathrm{day}^{-1}$ than outside $\left(3.80 \mathrm{~mm} \mathrm{day}^{-1}\right)$. Linear regression between $\mathrm{ET}_{\mathrm{o}, \text { in }}$ and $\mathrm{ET}_{\mathrm{O} \text {,out }}$ during the five years (Figure 11b; 1680 points) shows that $\mathrm{ET}_{\mathrm{o}, \text { in }}$ was reduced by about $27 \%$ compared to that outside. Similarly, in a banana screenhouse in Israel, Liu et al. [37] found that $\mathrm{ET}_{\mathrm{o} \text {,in }} \mathrm{was}$ reduced by $33 \%$ compared to outside because of the screen cover. In a semicircular shaped SG covered with a polyethylene film, crop water requirement inside decreased by 16-20\% compared to outside [48], that is generally similar to the $\mathrm{ET}_{\mathrm{o}}$ reduction result in this study. 



Figure 11. Daily reference crop evapotranspiration $\left(\mathrm{ET}_{\mathrm{O}}\right)$ inside and that outside of the sunken solar greenhouse during the seven seasons (a) and the linear relationships between inside and outside values (b). The black and red thin solid lines on (a) represent the 20-day moving averages of $\mathrm{ET}_{\mathrm{o}}$ inside and outside, respectively.

Radiation, temperature, vapor pressure deficit, and wind speed are the four meteorological factors that affect $\mathrm{ET}_{\mathrm{O}}[30,31]$. Because inside air velocity was low and nearly unchanged, only the relationships between $\mathrm{ET}_{\mathrm{o}, \mathrm{in}}$ and solar radiation, net radiation, temperature and VPD inside the SSG were analyzed, and results are shown in Figure 12. $\mathrm{ET}_{\mathrm{o} \text {,in }}$ was linearly related to all these four factors. The highest determination coefficient in the regression lines was 0.95 (Figure 12b) found for net radiation, followed by solar radiation ( 0.88 ; Figure 12a) and VDP (0.78; Figure 12d); the least was 0.57 for air temperature (Figure 12c). This suggests that $\mathrm{ET}_{\mathrm{o} \text {,in }}$ can be well estimated with the inside net radiation or solar radiation. This result can be confirmed by recalling Figure 10 where a high decoupling coefficient inside the SSG was obtained, indicating that crop evapotranspiration is mainly controlled by radiation. The slope of the linear regression line between $\mathrm{ET}_{\mathrm{O}, \text { in }}$ and inside solar radiation was 0.25 (Figure 12a), while it was 0.21 for outside solar radiation (Supplementary Figure S3). The inside higher value of 0.25 implies about $20 \%$ more solar energy is being converted to latent heat for crop evapotranspiration inside the SSG than that outside. Liu et al. [37] reported in a banana screenhouse that inside plant sap flow decreased by $10 \%$ compared to open field, however inside solar radiation was reduced by 
$20 \%$. Canopy conductance, which is positively related to transpiration, was found to be much higher under shading conditions for irrigated citrus, grapefruit, and apricot trees compared to those in open field [56-58], also representing a higher radiation use efficiency for low-radiation conditions under cover. It implies that although microclimate (excluding radiation) modifications are highly significant for avoiding low-temperature plant disaster, their effect on crop water use would probably be small.
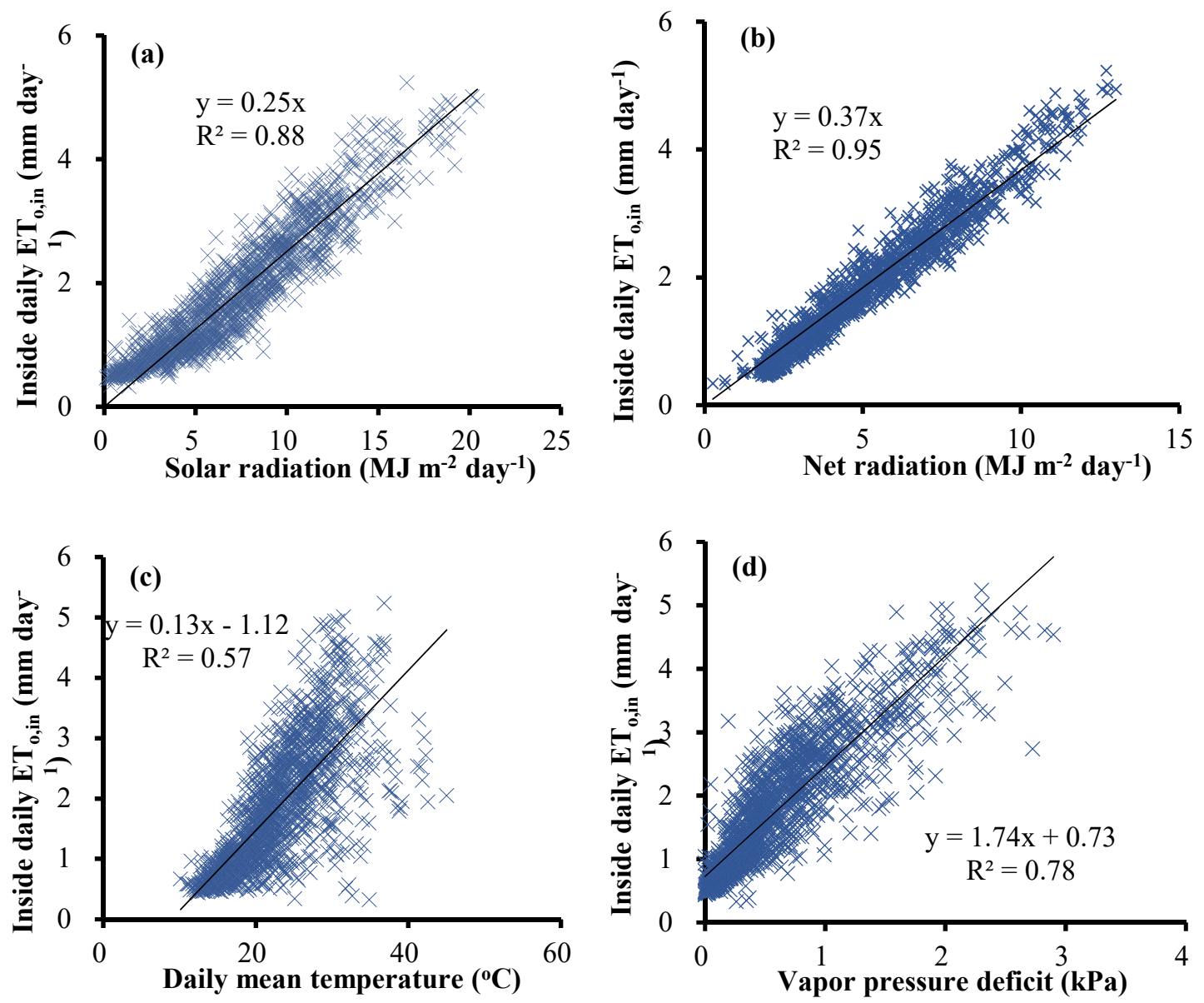

Figure 12. Relationships between inside reference crop evapotranspiration $\left(\mathrm{ET}_{\mathrm{o}, \mathrm{in}}\right)$ and solar radiation $(\mathbf{a})$, net radiation $(\mathbf{b})$, air temperature $(\mathbf{c})$ and vapor pressure deficit $(\mathbf{d})$ inside the sunken solar greenhouse.

The low determination coefficient of 0.57 in the air temperature regression (Figure 12c) indicates that estimating $\mathrm{ET}_{\mathrm{o}, \text { in }}$ using air temperature alone may cause a large error. Figure $12 \mathrm{~d}$ shows that $\mathrm{ET}_{\mathrm{o} \text {,in }}$ was linearly related to VPD with a determination coefficient of 0.78 , which is higher than that for air temperature, but lower than those for solar and net radiation (Figure 12a,b).

Mostly, farmers do not deploy meteorological stations inside greenhouses; however, they can usually get external climatic data from nearby weather stations. Therefore, we analyzed the relationship between inside $\mathrm{ET}_{\mathrm{o}, \text { in }}$ and external climatic factors. Results show that the inside $\mathrm{ET}_{\mathrm{o}, \text { in }}$ was linearly related to outside solar and net radiation with slopes of 0.157 and 0.277 , and determination coefficients

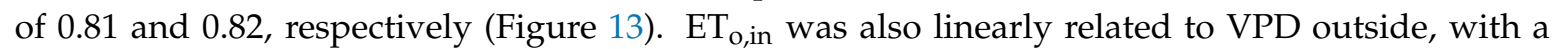
determination coefficient of 0.65 , and to air temperature with $\mathrm{R}^{2}$ of 0.53 (Supplementary Figure S4); both are much smaller than those for solar and net radiation (Figure 13a,b). The lower $\mathrm{R}^{2}$ for VPD and temperature are mainly because the greenhouse is covered with a plastic film, which impedes the exchanges of mass, heat, and momentum between the crop and the atmosphere outside. Therefore, inside climate is considerably isolated from outside (see also Figures 3,4 and 6), and inside ET $_{\mathrm{o} \text {,in }}$ is less connected to outside temperature and VPD. 

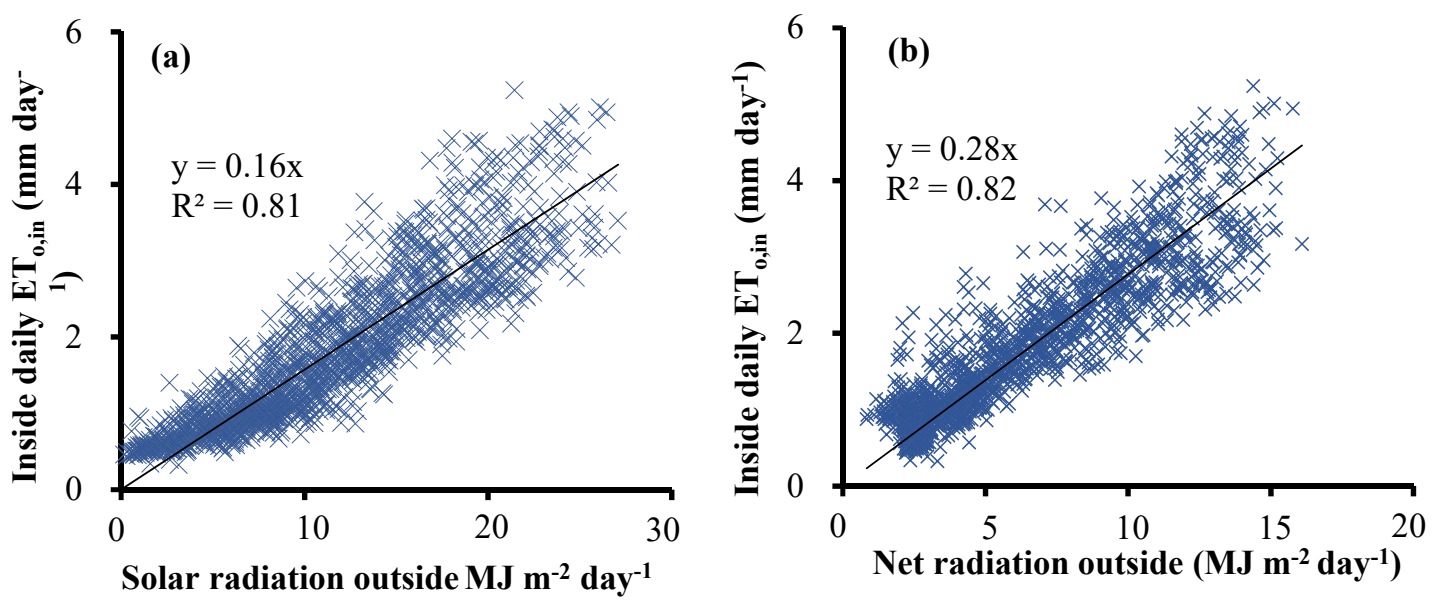

Figure 13. Relationship between inside reference crop evapotranspiration $\left(\mathrm{ET}_{\mathrm{O}, \text { in }}\right)$ and outside solar radiation (a) and net radiation $(\mathbf{b})$.

To quantify each climatic factor's effect on $\mathrm{ET}_{\mathrm{o}}$,in inside the $\mathrm{SSG}$, we calculated the mean daily value of each climatic variable both inside and outside over the experimental period. One climatic variable inside was replaced by its corresponding value outside and a modified $\mathrm{ET}_{\mathrm{o} \text {,in }}$ was calculated and compared to the outside $\mathrm{ET}_{\mathrm{O}, \text { out }}$ calculated using mean outside climatic data. Results showed that, mean $\mathrm{ET}_{\mathrm{o}}$ values were 2.11 and $1.58 \mathrm{~mm}$ day $^{-1}$ outside and inside, respectively, when their corresponding data were used. When inside relative humidity, air temperature, solar radiation, and wind speed were replaced by their corresponding outside values, $\mathrm{ET}_{\mathrm{o}, \text { in }}$ values were modified to 1.78 , $2.52,1.93$, and $1.63 \mathrm{~mm} \mathrm{day}^{-1}$, respectively, relative to the mean value of $1.58 \mathrm{~mm} \mathrm{day}^{-1}$. This result shows that increased relative humidity, and reduced radiation and wind speed resulted in $\mathrm{ET}_{0, \text { in }}$ reductions by $15.6 \%, 8.8 \%$, and $23.0 \%$, respectively. Increased inside temperature resulted in a $19.5 \%$ increase in $\mathrm{ET}_{\mathrm{o}, \mathrm{in}}$. The combined effect of all factors caused an $\mathrm{ET}_{\mathrm{o}, \text { in }}$ reduction by $25.1 \%$ compared to outside. This reduction is close to the value of $26.7 \%$ obtained from the regression in Figure $11 \mathrm{~b}$.

Similarly, Liu et al. [37] reported that the reduction in $\mathrm{ET}_{\mathrm{o}}$ of $33 \%$ inside a banana screenhouse was due to the reductions of wind speed $(15 \%)$, net radiation $(11 \%)$, and the increase of relative humidity (3\%). Moller et al. [39] reported that transpiration of sweet pepper in a 50-mesh insect-proof screenhouse was approximately $1.8-2.1 \mathrm{~mm} \mathrm{day}^{-1}$, also much lower than $4.5-5.3 \mathrm{~mm} \mathrm{day}^{-1}$ outside. They explained that the reduced radiation and wind velocity, as well as the modified vapor pressure deficit, were the main factors influencing inside transpiration.

\subsection{The Crop Coefficient}

Inside daily crop evapotranspiration $\left(\mathrm{ET}_{\mathrm{C}}\right)$ was estimated using the Penman-Monteith method by Equation (6). Generally, inside daily $\mathrm{ET}_{\mathrm{c}}$ was lower than $4 \mathrm{~mm}$ day $^{-1}$. Basal crop coefficient $\left(\mathrm{K}_{\mathrm{cb}}\right)$ is defined as the ratio of crop evapotranspiration to reference crop evapotranspiration [30]. Figure 14 shows the relationship between crop $\mathrm{ET}_{\mathrm{c}}$ and $\mathrm{ET}_{\mathrm{o}, \text { in }}$ inside the SSG. It can be observed that daily $\mathrm{ET}_{\mathrm{c}}$ was linearly related to $\mathrm{ET}_{\mathrm{o}, \text { in }}$. The slope of the linear regression line, 0.83 , can be regarded as the basal crop coefficient. This $\mathrm{K}_{\mathrm{cb}}$ value is smaller than 0.95 recommended by Allen et al. [30], however, the crop coefficient is generally low in humid and low-wind environments. Therefore, the $\mathrm{K}_{\mathrm{cb}}$ value recommended by Allen et al. [30] can be adjusted by climate condition using $K_{\mathrm{cb}, \text { adj }}=K_{\mathrm{cb}}+\left[0.04\left(u_{2}-2\right)-0.04\left(R H_{\min }-45\right) \times\left(\frac{h}{3}\right)^{0.3}\right]$, where $u_{2}$ is wind speed, $R H_{\min }$ is the mean value of daily minimum relative humidity during the mid- or late-season growth stage and $h$ is the average plant height [30]. For the conditions of the present study, the $\mathrm{K}_{\mathrm{cb}}$ adjusted from the recommended values of 0.95 was obtained as 0.77 which is relatively close to 0.83 of this study. Further, Allen et al. [30] reported that an increased recommended $K_{c b}$ can be taken when the cucumber is 
grown on stalks reaching 1.5-2 m high. When this factor is considered, the $\mathrm{K}_{\mathrm{cb}}$ of 0.83 obtained in this study is acceptable.

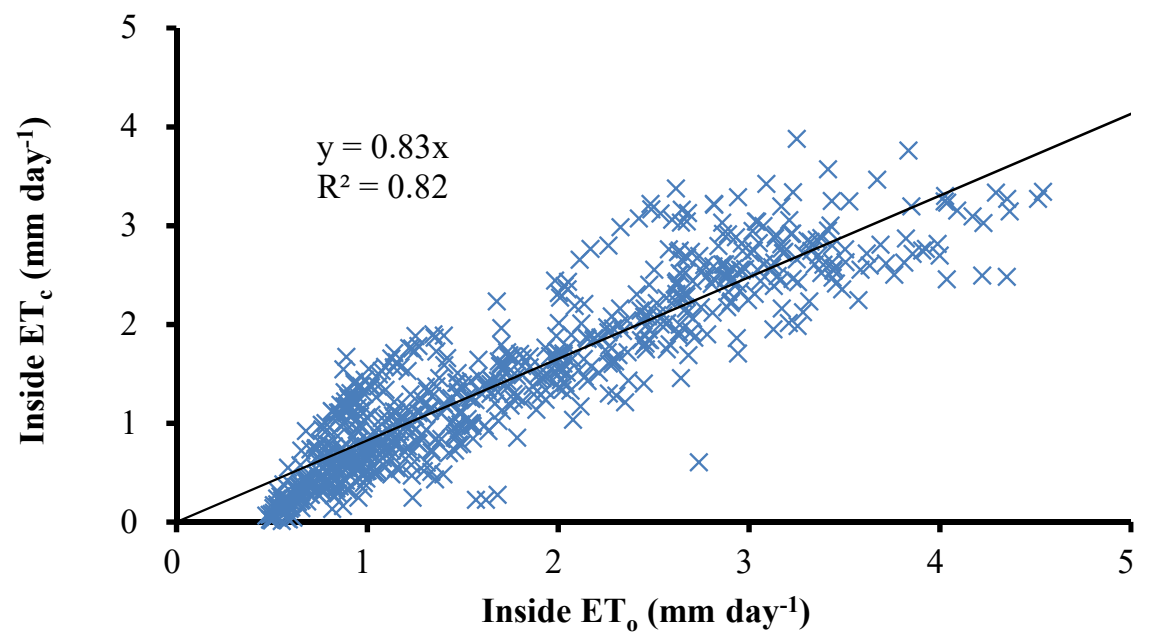

Figure 14. The relationship between estimated crop evapotranspiration $\left(\mathrm{ET}_{\mathrm{c}}\right)$ and reference crop evapotranspiration inside the sunken solar greenhouse $\left(\mathrm{ET}_{\mathrm{O}, \text { in }}\right)$ during the experimental period.

In the $\mathrm{ET}_{\mathrm{c}}$ calculation process, we have two assumptions. One is that the albedo of the cucumber canopy is 0.23 , the same as the reference grass in the $\mathrm{ET}_{\mathrm{o}}$ calculation. Another is that the outward and downward longwave radiations from the cover of the greenhouse are the same. Therefore, the effect of the cover on net longwave radiation is not considered. Both assumptions could induce errors. Therefore, we explain that the crop $\mathrm{ET}_{\mathrm{c}}$ inside the SSG is roughly estimated. The calculated basal crop coefficient of 0.83 falls into the range (0.77-0.95) proposed by Allen et al. [30], which means that the estimated $\mathrm{ET}_{\mathrm{C}}$ is acceptable.

\subsection{SSG Management and Design}

It is clear from this study that the SSG could greatly increase inside air and soil temperature during winter (Figures 2, 3 and 8), which, in turn, enhances cucumber crop growth and fresh cucumber yield (Section 3.1). The main reasons for the improvement of these microclimate conditions are the deeper soil surface and thicker back wall as compared with the traditional SG. Deep soil surface could largely impede the heat exchange between inside and outside, reduce the heat losses, and keep relatively high inside temperature. The thick back wall could store more heat in sunny days and release it into the greenhouse to increase environmental temperature during nights or cloudy days $[8,15,54]$. Further, the thick back wall could increase the heat transfer resistance to outside and reduce heat losses. Considering the improved performance and environmental benefit, the SSG could be recommended for crop cultivation in winter or in other regions in the world with low air temperatures.

All data in this study is from a typical SSG, in which soil surface is $1.5 \mathrm{~m}$ deep and the thickness of the back wall is changing from bottom to top ( $8 \mathrm{~m}$ at bottom to $2 \mathrm{~m}$ at top in this SSG). Measured data shows inside temperature was greatly improved and cucumber yield increased in the study region. However, in regions with other outside climate conditions, the soil surface depth and the back wall thickness should be optimized to induce optimal microclimate for crop growth and production. Also, in summer, when outside temperature is high, the inside temperature is much higher than that outside in daytime (Figure 3), due to the low ventilation capacity from the vent at the top of the SSG (Figure 1). Therefore, some measures, like shading or flexible venting, should be considered to reduce inside heat load [12]. Considering that the SSG has been only used during the recent few years, the mechanisms of heat and mass transfer, microclimate change, and crop response is not clear and should be comprehensively studied in future research. Besides experimental studies like that presented in this 
paper, corresponding mathematical models of SSG performance should be also developed to optimize the SSG structure.

\section{Conclusions}

The main conclusions of this study are:

(1) The sunken solar greenhouse significantly improved microclimate conditions in the winter period by increasing the daily minimum air temperature to more than $10^{\circ} \mathrm{C}$, even when the outside air temperature was lower than $-10^{\circ} \mathrm{C}$. This change can efficiently reduce low-temperature injures and enhance crop growth. Days with inside temperatures higher than $20^{\circ} \mathrm{C}$ accounted for $78-90 \%$ of the total winter period, which significantly improved the microclimate condition and enhanced cucumber growth and yield.

(2) $\mathrm{ET}_{\mathrm{o}, \mathrm{in}}$ inside, was linearly related to that outside with a slope of 0.73 . The approximately $27 \%$ lower inside than outside $\mathrm{ET}_{\mathrm{O}, \text { out }}$ was due to the wind speed reduction $(-23.0 \%)$, relative humidity increase $(-15.6 \%)$, radiation reduction $(-8.8 \%)$, and air temperature increase $(19.5 \%)$.

(3) The decoupling coefficient ranged from 0.8 to 0.9 during daytime, mainly because of the low internal wind speed, indicating a highly decoupled environment.

(4) The estimated crop $\mathrm{ET}_{\mathrm{c}}$ was generally lower than $4 \mathrm{~mm} \mathrm{day}^{-1}$, and was linearly related to $\mathrm{ET}_{\mathrm{o}, \text { in }}$. The basal crop coefficient during the middle growth stage inside the SSG was 0.83.

(5) The SSG is an environmentally friendly structure for cash crop cultivation, especially in the winter period, when the inside microclimate is much improved.

Supplementary Materials: The following are available online at http://www.mdpi.com/2073-4441/12/8/2275/s1, Figure S1: The relationships between daily maximum (a) and mean (b) soil temperatures at 10 and $20 \mathrm{~cm}$ depth to those at the soil surface $(0 \mathrm{~cm}$ depth) inside the sunken solar greenhouse. Ts,mean-10, Ts,mean-20, Ts,max-10 and Ts,max-20 on figures are daily mean soil temperatures at 10 and $20 \mathrm{~cm}$ depth, and daily maximum soil temperatures at 10 and $20 \mathrm{~cm}$ depth, respectively; Figure S2: The relationships between daily maximum (a), minimum (b) and mean (c) soil temperatures at $20 \mathrm{~cm}$ depth to their corresponding soil temperatures at $10 \mathrm{~cm}$ depth; Figure S3: The relationships between daily $\mathrm{ET}_{\mathrm{o}}$ and solar radiation outside the sunken solar greenhouse (SSG); and Figure S4: The relationships between inside daily $\mathrm{ET}_{\mathrm{O}}$ and outside daily mean air temperature (a) and vapor pressure deficit (b).

Author Contributions: Conceptualization: H.L.; methodology: H.L.; formal analysis: H.L., C.Y., and X.T.; investigation and data curation: X.H., C.Y., and X.T.; writing-original draft preparation: H.L.; writing一review and editing: H.L. and J.T.; All authors have read and agreed to the published version of the manuscript.

Funding: This work was financially supported by the National Nature Science Foundation of China (NO. 91479004, 51939005) and the 111 Project (B18006).

Acknowledgments: The authors greatly appreciated the field support of Chaoyang Sun, the owner of the sunken solar greenhouse. The authors also greatly appreciated the helpful comments and suggestions by the two anonymous reviewers.

Conflicts of Interest: The authors declare no conflict of interest.

\section{References}

1. Panwar, N.L.; Kaushik, S.C.; Kothari, S. Solar greenhouse an option for renewable and sustainable farming. Renew. Sustain. Energy Rev. 2011, 15, 3934-3945. [CrossRef]

2. Sanchez-Molina, J.; Ming, L.; Rodriguez, F.; Guzman, J.; Hui, W.; Xinting, Y. Development and test verification of air temperature model for Chinese solar and Spainish Almeria-type greenhouses. Int. J. Agric. Biol. Eng. 2017, 10, 66-76. [CrossRef]

3. Robert, F.; Alex, Z. Solar Greenhouse Technology for Food Security: A Case Study From Humla District, NW Nepal. Mt. Res. Dev. 2012, 32, 411-419. [CrossRef]

4. Qiu, R.; Du, T.; Kang, S.; Chen, R.; Wu, L. Assessing the SIMDualKc model for estimating evapotranspiration of hot pepper grown in a solar greenhouse in Northwest China. Agric. Syst. 2015, 138, 1-9. [CrossRef]

5. Song, H.; Guo, J.; Ren, T.; Chen, Q.; Li, B.; Wang, J. Increase of Soil pH in a Solar Greenhouse Vegetable Production System. Soil Sci. Soc. Am. J. 2012, 76, 2074-2082. [CrossRef] 
6. Liang, X.; Gao, Y.; Zhang, X.; Tian, Y.; Zhang, Z.; Gao, L. Effect of optimal daily fertigation on migration of water and salt in soil, root growth and fruit yield of cucumber (Cucumis sativus L.) in solar-greenhouse. PLoS ONE 2014, 9, e86975. [CrossRef]

7. Wang, J.; Li, S.; Hong, Z.; Sun, J.; Wang, J.; Guo, S. Evaluating selection criteria for Chinese solar greenhouses: A case study for northern Jiangsu Province. Appl. Eng. Agric. 2016, 32, 401-413. [CrossRef]

8. Chen, S.; Li, Z.; Liu, F.; Yang, S.; Li, M. Risk evaluation of solar greenhouse cucumbers low temperature disaster based on GIS spatial analysis in Tianjin, China. Geomat. Natl. Haz. Risk 2019, 10, 576-598. [CrossRef]

9. Ni, M.; Lan, D.; Jahan, M.; Wang, J.; Guo, S. A pilot study on the microclimate of a multi-span solar energy greenhouse. Appl. Eng. Agric. 2019, 35, 601-616. [CrossRef]

10. Li, A.; Huang, L.; Zhang, T. Field test and analysis of microclimate in naturally ventilated single-sloped greenhouses. Energy Build. 2017, 138, 479-489. [CrossRef]

11. Singh, M.C.; Singh, J.P.; Singh, K.G. Development of a microclimate model for prediction of temperatures inside a naturally ventilated greenhouse under cucumber crop in soilless media. Comput. Electron. Agric. 2018, 154, 227-238. [CrossRef]

12. Saberian, A.; Sajadiye, S.M. The effect of dynamic solar heat load on the greenhouse microclimate using CFD simulation. Renew. Energy 2019, 138, 722-737. [CrossRef]

13. Baddadi, S.; Bouadila, S.; Guizani, A. Beneficial use of two packed beds of latent storage energy for the heating of a hydroponic greenhouse. Energy Procedia 2019, 162, 156-163. [CrossRef]

14. Gourdo, L.; Fatnassi, H.; Bouharroud, R.; Ezzaeri, K.; Bazgaou, A.; Wifaya, A.; Demrati, H.; Bekkaoui, A.; Aharoune, A.; Poncet, C.; et al. Heating canarian greenhouse with a passive solar water-sleeve system: Effect on microclimate and tomato crop yield. Sol. Energy 2019, 188, 1349-1359. [CrossRef]

15. Hassanain, A.A.; Hokam, E.M.; Mallick, T.K. Effect of solar storage wall on the passive solar heating constructions. Energy Build. 2011, 43, 737-747. [CrossRef]

16. Ntinas, G.K.; Koukounaras, A.; Kotsopoulos, T. Effect of energy saving solar sleeves on characteristics of hydroponic tomatoes grown in a greenhouse. Sci. Hortic. 2015, 194, 126-133. [CrossRef]

17. Shukla, A.; Sharma, A.; Kant, K. Solar Greenhouse With Thermal Energy Storage: A Review. Curr. Sustain. Renew. Energy Rep. 2016, 3, 58-66. [CrossRef]

18. Tong, X.; Sun, Z.; Sigrimis, N.; Li, T. Energy sustainability performance of a sliding cover solar greenhouse: Solar energy capture aspects. Biosyst. Eng. 2018, 176, 88-102. [CrossRef]

19. Ahamed, M.S.; Guo, H.; Tanino, K. Sensitivity analysis of CSGHEAT model for estimation of heating consumption in a Chinese-style solar greenhouse. Comput. Electron. Agric. 2018, 154, 99-111. [CrossRef]

20. Xu, D.; Du, S.; van Willigenburg, L.G. Optimal control of Chinese solar greenhouse cultivation. Biosyst. Eng. 2018, 171, 205-219. [CrossRef]

21. Hodge, C.; Rogers, M.; Handeen, D.; Schweser, G. Yield of leafy greens and microclimate in deep winter greenhouse production in Minnesota. Sustainability 2019, 11, 28. [CrossRef]

22. Zhang, B.; Fan, X.; Liu, M.; Hao, W. Experimental study of the burning-cave hot water soil heating system in solar greenhouse. Renew. Energy 2016, 87, 1113-1120. [CrossRef]

23. Canakci, M.; Yasemin Emekli, N.; Bilgin, S.; Caglayan, N. Heating requirement and its costs in greenhouse structures: A case study for Mediterranean region of Turkey. Renew. Sustain. Energy Rev. 2013, 24, 483-490. [CrossRef]

24. Lazaar, M.; Bouadila, S.; Kooli, S.; Farhat, A. Comparative study of conventional and solar heating systems under tunnel Tunisian greenhouses: Thermal performance and economic analysis. Sol. Energy 2015, 120, 620-635. [CrossRef]

25. Alter, R.E.; Douglas, H.C.; Winter, J.M.; Eltahir, E.A.B. Twentieth century regional climate change during the summer in the Central United States attributed to agricultural intensification. Geophys. Res. Lett. 2018, 45, 1586-1594. [CrossRef]

26. Anderson, K.; Peters, G. The trouble with negative emissions. Science 2016, 354, 182-183. [CrossRef]

27. Noorollahi, Y.; Bigdelou, P.; Pourfayaz, F.; Yousefi, H. Numerical modeling and economic analysis of a ground source heat pump for supplying energy for a greenhouse in Alborz province, Iran. J. Clean. Prod. 2016, 131, 145-154. [CrossRef]

28. Ahamed, M.S.; Guo, H.; Tanino, K. Modeling heating demands in a Chinese-style solar greenhouse using the transient building energy simulation model TRNSYS. J. Build. Eng. 2020, 29, 101114. [CrossRef] 
29. Medrano, E.; Lorenzo, P.; Sánchez-Guerrero, M.C.; Montero, J.I. Evaluation and modelling of greenhouse cucumber-crop transpiration under high and low radiation conditions. Sci. Hortic. 2005, 105, 163-175. [CrossRef]

30. Allen, R.G.; Pereira, L.S.; Raes, D.; Smith, M. Crop Evapotranspiration: Guidelines for Computing Crop Water Requirements; Food and Agriculture Organization of the United Nations: Rome, Italy, 1998.

31. Fernández, M.D.; Bonachela, S.; Orgaz, F.; Thompson, R.; López, J.; Granados, M.; Gallardo, M.; Fereres, E. Measurement and estimation of plastic greenhouse reference evapotranspiration in a Mediterranean climate. Irrig. Sci. 2010, 28, 497-509. [CrossRef]

32. Fernández, M.D.; Bonachela, S.; Orgaz, F.; Thompson, R.B.; López, J.C.; Granados, M.R.; Gallardo, M.; Fereres, E. Erratum to: Measurement and estimation of plastic greenhouse reference evapotranspiration in a Mediterranean climate. Irrig. Sci. 2011, 29, 91-92. [CrossRef]

33. Yang, X.; Short, T.H.; Fox, R.D.; Bauerle, W.L. Transpiration, leaf temperature and stomatal resistance of a greenhouse cucumber crop. Agric. For. Meteorol. 1990, 51, 197-209. [CrossRef]

34. Huang, S.; Yan, H.; Zhang, C.; Wang, G.; Acquah, S.J.; Yu, J.; Li, L.; Ma, J.; Opoku Darko, R. Modeling evapotranspiration for cucumber plants based on the Shuttleworth-Wallace model in a Venlo-type greenhouse. Agric. Water Manag. 2020, 228, 105861. [CrossRef]

35. Yan, H.; Huang, S.; Zhang, C.; Gerrits, C.M.; Wang, G.; Zhang, J.; Zhao, B.; Acquah, J.S.; Wu, H.; Fu, H. Parameterization and application of Stanghellini Model for estimating greenhouse cucumber transpiration. Water 2020, 12, 517. [CrossRef]

36. Chen, L.-H.; Chen, J.; Chen, C. Effect of environmental measurement uncertainty on prediction of evapotranspiration. Atmosphere 2018, 9, 400. [CrossRef]

37. Liu, H.; Cohen, S.; Hugo, L.J.; Yair, I.; Josef, T. Sap flow, canopy conductance and microclimate in a banana screenhouse. Agric. For. Meteorol. 2015, 201, 165-175. [CrossRef]

38. Monteith, J.L.; Unsworth, M.H. Principles of Environmental Physics, 4th ed.; Academic Press: Oxford, UK, 2013.

39. Moller, M.; Tanny, J.; Li, Y.; Cohen, S. Measuring and predicting evapotranspiration in an insect-proof screenhouse. Agric. For. Meteorol. 2004, 127, 35-51. [CrossRef]

40. Rouphael, Y.; Colla, G. Modelling the transpiration of a greenhouse zucchini crop grown under a Mediterranean climate using the Penman-Monteith equation and its simplified version. Aust. J. Agric. Res. 2004, 55, 931-937. [CrossRef]

41. Nikolaou, G.; Neocleous, D.; Katsoulas, N.; Kittas, C. Modelling transpiration of soilless greenhouse cucumber and its relationship with leaf temperature in a mediterranean climate. Emir. J. Food Agric. 2017, 29, 911-920. [CrossRef]

42. Yan, H.; Acquah, S.J.; Zhang, C.; Wang, G.; Huang, S.; Zhang, H.; Zhao, B.; Wu, H. Energy partitioning of greenhouse cucumber based on the application of Penman-Monteith and Bulk Transfer models. Agric. Water Manag. 2019, 217, 201-211. [CrossRef]

43. Zhang, L.; Gao, L.; Zhang, L.; Wang, S.; Sui, X.; Zhang, Z. Alternate furrow irrigation and nitrogen level effects on migration of water and nitrate-nitrogen in soil and root growth of cucumber in solar-greenhouse. Sci. Hortic. 2012, 138, 43-49. [CrossRef]

44. Hossain, S.A.A.M.; Wang, L.; Liu, H. Improved greenhouse cucumber production under deficit water and fertilization in Northern China. Int. J. Agric. Biol. Eng. 2018, 11, 58-64.

45. Rahil, M.H.; Qanadillo, A. Effects of different irrigation regimes on yield and water use efficiency of cucumber crop. Agric. Water Manag. 2015, 148, 10-15. [CrossRef]

46. Sun, Y.; Zhang, J.; Wang, H.; Wang, L.; Li, H. Identifying optimal water and nitrogen inputs for high efficiency and low environment impacts of a greenhouse summer cucumber with a model method. Agric. Water Manag. 2019, 212, 23-34. [CrossRef]

47. Amer, K.; Midan, S.; Hatfield, J. Effect of deficit irrigation and fertilization on cucumber. Agron. J. 2009, 101, 1556-1564. [CrossRef]

48. Abdalhi, M.A.M.; Cheng, J.; Feng, S.; Yi, G. Performance of drip irrigation and nitrogen fertilizer in irrigation water saving and nitrogen use efficiency for waxy maize (Zea mays L.) and cucumber (Cucumis sativus L.) under solar greenhouse. Grassl. Sci. 2016, 62, 174-187. [CrossRef]

49. FAOSTAT. Food and Agriculture Data; Food and Agriculture Organization of the United Nations: Rome, Italy, 2020. 
50. National Bureau of Statistics of China. China National Statistical Yearbook; China Statistics Press: Beijing, China, 2019.

51. Graamans, L.; Baeza, E.; Dobbelsteen, V.D.A.; Tsafaras, I.; Stanghellini, C. Plant factories versus greenhouses: Comparison of resource use efficiency. Agric. Syst. 2018, 160, 31-43. [CrossRef]

52. Kitta, E.; Katsoulas, N.; Savvas, D. Shading effects on greenhouse microclimate and crop transpiration in a cucumber crop grown under mediterranean conditions. Appl. Eng. Agric. 2012, 28, 129-140. [CrossRef]

53. Heidari, M.D.; Omid, M.; Mohammadi, A. Measuring productive efficiency of horticultural greenhouses in Iran: A data envelopment analysis approach. Expert Syst. Appl. 2012, 39, 1040-1045. [CrossRef]

54. Ren, J.; Zhao, Z.; Zhang, J.; Wang, J.; Guo, S.; Sun, J. Study on the hygrothermal properties of a Chinese solar greenhouse with a straw block north wall. Energy Build. 2019, 193, 127-138. [CrossRef]

55. Li, M.; Chen, S.; Liu, F.; Zhao, L.; Xue, Q.; Wang, H.; Chen, M.; Lei, P.; Wen, D.; Sanchez-Molina, J.; et al. A risk management system for meteorological disasters of solar greenhouse vegetables. Precis. Agric. 2017, 18, 997-1010. [CrossRef]

56. Cohen, S.; Moreshet, S.; Le Guillou, L.; Simon, J.C.; Cohen, M. Response of citrus trees to modified radiation regime in semi-arid conditions. J. Exp. Bot. 1997, 48, 35-44. [CrossRef]

57. Cohen, S.; Raveh, E.; Li, Y.; Grava, A.; Goldschmidt, E.E. Physiological responses of leaves, tree growth and fruit yield of grapefruit trees under reflective shade screens. Sci. Hortic. 2005, 107, 25-35. [CrossRef]

58. Barradas, V.L.; Nicolás, E.; Torrecillas, A.; Alarcón, J.J. Transpiration and canopy conductance in young apricot (Prunus armenica L.) trees subjected to different PAR levels and water stress. Agric. Water Manag. 2005, 77, 323-333. [CrossRef]

(C) 2020 by the authors. Licensee MDPI, Basel, Switzerland. This article is an open access article distributed under the terms and conditions of the Creative Commons Attribution (CC BY) license (http://creativecommons.org/licenses/by/4.0/). 